\title{
Lost in transition? The persistence of dictatorship mayors*
}

\author{
Felipe González \\ Pablo Muñoz \\ Mounu Prem
}

\begin{abstract}
We look at Chile's transition to democracy in 1990 to study the persistence of authoritarian politics at the local level. Using new data on the universe of mayors appointed by the Pinochet dictatorship (1973-1990), and leveraging on the arbitrary election rules that characterized the first local election in 1992, we present two main findings. First, dictatorship mayors obtained a vote premium that is larger among the last wave of incumbents and appears partially explained by an increase in local spending. Second, dictatorship mayors who were democratically elected in 1992 brought votes for the parties that collaborated with the dictatorship in subsequent elections held in democracy. These results show that the body of politicians appointed by a dictatorship can contribute to the persistence of elites and institutions.
\end{abstract}

Keywords: politicians, dictatorship, democratic transition

\footnotetext{
*January 2021. We would like to thank seminar participants at the Annual Economic History and Cliometrics Lab Conference at the Pontificia Universidad Católica de Chile, the Rosario-Andes Taller Applied, and the USACHOxford Conference on Electoral Manipulation and Corruption. We are grateful to the Center for Effective Global Action, Coordenação de Aperfeiçoamento de Pessoal de Nível Superior - Brasil (CAPES) - Finance Code 00, the Economic History Association, Fondecyt Project 11170258, and the Stanford Center for International Development for financial support. Luis Serrano, Luisa Oyuela, and Cristine von Dessauer provided outstanding research assistance. González: Pontificia Universidad Católica de Chile, Instituto de Economía. Muñoz: FGV-EPGE Brazilian School of Economics and Finance. Prem: Universidad del Rosario, Department of Economics.
} 


\section{Introduction}

Social scientists argue that there is an important link between the authoritarian past of a country and the degree of elite capture observed in democracy. ${ }^{1}$ These authoritarian legacies are particularly relevant when a democratization changes the distribution of de jure political power but has limited changes in de facto political power. This was partially the case in Indonesia where dictatorship mayors remained in office for arbitrary reasons and facilitated elite capture (Martínez Bravo et al., 2017). Yet many transitions lack this type of arbitrary persistence of mayors and unfold relatively more slowly, providing elites with time to prepare for upcoming democratic elections. For example, political elites might decide to invest in de facto power through the provision of public goods before the transition unfolds. Although intuitive, empirical evidence for this mechanism is limited.

We leverage new historical data together with transitory electoral rules around Chile's democratization in 1990 to offer two findings that improve our understanding of elite persistence. First, mayors appointed by the Pinochet dictatorship (1973-1990) obtained a vote premium of 9 percentage points (pp.) in the first local election held in democracy (1992). This premium was twice as large (12 vs 6 pp.) for the subset of dictatorship mayors who decided to run in the municipality where they were the sitting incumbent. Further analysis suggests that an increase in local spending before the transition can partially explain the vote premium of all dictatorship mayors. Second, when looking at subsequent elections held in democracy we find that dictatorship mayors who were democratically elected brought additional votes for the parties that collaborated with the former dictatorship, without affecting outcomes related to the performance of local governments.

Chile's transition to democracy is an interesting case study for several reasons. The Pinochet dictatorship exhibited many of the key features of twentieth-century authoritarian governments, including state-led repression (Bautista et al., 2020), media censorship (Chen and Yang, 2019), concentrated power in a single person (Geddes et al., 2018), and democratization by election (Treisman, 2020). Immediately after the 1973 coup d'état, a military junta removed all democratically elected mayors and appointed local officials that were "to be trusted." The transition

\footnotetext{
${ }^{1}$ See, for instance, O’Donnell and Schmitter (1986); Linz and Stepan (1996); Acemoglu (2008); Acemoglu and Robinson (2008); Acemoglu et al. (2011); Albertus and Menaldo (2018); Nunn (2020).
} 
to democracy began in October of 1988, when Augusto Pinochet lost a well-known referendum under international scrutiny. A new democratic government was elected in 1989, which took office in March 1990, and local elections were held in June 1992 to decide the new body of mayors.

Despite extensive literature studying the Pinochet regime (Huneeus, 2006; Cavallo et al., 2011), very little is known about local governments and appointed mayors. We contribute with new evidence on this topic using vast amounts of recorded but previously unexplored data, i.e. the appointments of all mayors during this period. These appointments were discretionary and a descriptive analysis of the temporal dynamics in the appearance of new mayors in a municipality suggests that these were unrelated to performance: protests, natural disasters, and poor budget management were unrelated to the replacement of mayors. Although we stress that the Pinochet regime could have appointed mayors based on other unobserved dimensions, we interpret these patterns as suggestive evidence that authoritarian appointments were associated with poor monitoring and selection of government officials (Myerson, 2015; Martínez Bravo et al., 2020).

To study the persistence of dictatorship mayors, we followed them in local elections in democracy and digitized data on local spending by municipality. We begin by documenting that dictatorship mayors who ran in the first local election in 1992 obtained a vote premium of $9 \mathrm{pp}$. This premium was twice as large for the last wave of dictatorship mayors who decided to run in the municipality where they were sitting incumbents. Moreover, an analysis of the second election in 1996 suggests that this "incumbency effect" is similar to the well-known advantage obtained by elected mayors in democracy (Lee, 2008). Motivated by a sharp increase in local spending after it was revealed Pinochet would leave office (October 1988 to March 1990), we study whether this spending helped dictatorship mayors to gain votes in the first local election in democracy. We find that a one standard deviation increase in local spending increased their vote share by $3 \mathrm{pp}$. This finding is consistent with recent research (Voigtländer and Voth, 2018), supports the hypothesis that political elites provided additional public goods to prepare for the upcoming elections, and can explain at least part of the incumbency effect we document.

What are the political and economic consequences of dictatorship mayors serving in a new democratic time? Since dictatorship mayors were not randomly elected across municipalities, we 
exploit quasi-experimental variation coming from the transitory electoral rules that characterized the first local elections. These rules allow us to approximate a natural experiment in which dictatorship mayors were close to being randomly elected as mayors in a subset of municipalities. Using this source of variation we show that dictatorship mayors were associated with a higher vote share for right-wing candidates in subsequent local and presidential elections, a higher share of right-wing politicians elected for the local council, but do not seem to have affected the economic performance of local governments. Since the right-wing coalition collaborated with the Pinochet dictatorship, we interpret these results as evidence of dictatorship mayors being one mechanism through which authoritarian elites persist across political regimes.

This paper contributes to the literature documenting the legacies of dictatorships and more generally the functioning of young democracies with an authoritarian past. Although several authors have emphasized the link between authoritarian regimes and subsequent democracies (O'Donnell and Schmitter, 1986; Huntington, 1991; Linz and Stepan, 1996), empirical studies have only appeared recently. There is evidence that local officials inherited from a dictatorship affected clientelistic spending and facilitated elite capture in Indonesia (Martínez Bravo, 2014; Martínez Bravo et al., 2017). In contrast to the Indonesian case, Chile's transition was less abrupt and consequently appointed mayors - and the elite more generally - had time to prepare for the upcoming democracy (González and Prem, 2020). In this regard, we contribute to a literature documenting the strategies used by elites to maintain their power (Robinson and Hadiz, 2004; Honna, 2010; Albertus and Menaldo, 2014, 2018; González et al., 2020; Aldunate et al., 2020). In addition, by empirically studying the fate of mayors appointed by a dictatorship, our paper also contributes to the literature studying elite persistence (Acemoglu and Robinson, 2008; Albertus, 2019; Ferraz et al., 2020).

We also contribute to a literature that studies appointments to local governments. Research in democracies is vast - see Dal Bó and Finan (2018) for a review - but there is less evidence from autocracies. Many authoritarian regimes use local elections, but some do not. ${ }^{2}$ When dictators select mayors the drivers of appointments are unknown. There is, however, evidence of

\footnotetext{
${ }^{2}$ Examples of authoritarian regimes with local elections include Brazil (1964-1985), Indonesia (1968-1998), Pakistan (1977-1988), and China (1980s-1990s), among others. Martínez Bravo et al. (2020) argues that the existence of local elections in authoritarian regimes can be explained by information asymmetries.
} 
patronage among public officials different from mayors in the British Empire and current democracies (Xu, 2018; Colonnelli et al., 2020). A related literature shows that elected officials respond more to their constituents than appointed ones due to electoral incentives (Besley and Coate, 2003; Levin and Tadelis, 2010; Choi et al., 2010; Hessami, 2018). Our contribution is twofold. First, we show descriptive evidence suggesting that appointments of mayors in dictatorship were unrelated to performance. Second, we show that "once appointed" (then elected) mayors perform similarly to "never appointed" ones but increase the vote share of their parties. The increase in votes is consistent with a literature studying political dynasties in dictatorships (Brownlee, 2007) and democracies (Dal Bó et al., 2009), but across-regime evidence is more limited.

Finally, we contribute to the literature studying how local spending can affect voting patterns. Previous research has shown that local spending can boost political support because - when efficient - it signals economic competence and - when targeted - it spreads support through social networks (Berman et al., 2011; Voigtländer and Voth, 2018; Fafchamps and Labonne, 2020). Moreover, elections can provide political incentives to complete projects and voters reward incumbents for doing so (Marx, 2018). ${ }^{3}$ We contribute to this literature by showing how an authoritarian regime might benefit from local spending and maintain their political power after a democratization.

\section{Historical background}

The last local election before the Pinochet dictatorship (1973-1990) was held in April 1971 under the government of socialist Salvador Allende (1970-1973). In this election the coalition of leftwing parties known as Popular Unity, which supported Allende in the 1970 presidential election, obtained more than $50 \%$ of the vote. ${ }^{4}$ After the 1973 coup d'état, a military junta ruled the country and suspended the constitution, removed all democratically elected mayors, and appointed a new body of mayors that were "to be trusted" (Decree Law N. 25). Fifteen years later Augusto Pinochet

\footnotetext{
${ }^{3}$ Related work has also shown how targeted income transfers or even random income shocks can increase support for the incumbent government (Manacorda et al., 2011; Labonne, 2013; Bagues and Esteve-Volart, 2016). There is also a vast literature estimating the local non-political effects of infrastructure projects (e.g. Michaels 2008; Faber 2014; Hornbeck and Donaldson 2016; Donaldson 2018).

${ }^{4}$ In terms of political parties, the winner of that election was the Christian Democrats (political center) with 26\% of the votes, followed closely by the Socialist Party (left-wing) with 23\%, and then by the National Party (right-wing) with $18 \%$ of the votes.
} 
lost a referendum and the transition to democracy unfolded. The new democratically elected government took office in March 1990 and local elections were held in June 1992 to decide the new body of mayors. Figure 1 presents a timeline of the main political events.

\subsection{Mayors in dictatorship}

There is a vast literature studying the Pinochet regime (e.g. Huneeus 2006; Cavallo et al. 2011). Yet we know much less about local governments and appointed mayors. Perhaps the most detailed account of the importance of local governments during this period comes from Valdivia et al. (2012). The authors argue that from the beginning of the 1980s municipalities became key for the implementation of the regime's policy platform, particularly social policies. ${ }^{5}$ The regime attempted to effectively change the policy-deliberation process from traditional institutions like the Congress and political parties to local areas. Mayors became more important and had de facto power over the functioning of municipalities, with regidores in the Consejo de Desarrollo Comunal - i.e. the Council - serving only as advisors. Of course, in practice there were differences in the importance of mayors, presumably based on the number of people they served and their proximity to the capital (Valdivia et al., 2012; Matus, 2014). Despite all of these important changes in the role of mayors, we know very little about their appointments and fate after the return to democracy.

The 1980 Constitution crafted by the Pinochet regime established that mayors were to be appointed by the President and would last four years in power. The opposition was critical of this change which they argued broke a long-standing democratic tradition (Díaz and Maturana, 1994). Unfortunately, most information about the selection and removal of mayors comes only from anecdotes and interviews. For example, some members of right-wing parties seem to have started their political careers as appointed mayors and then got elected as members of the Congress in parliamentary elections or as mayors in local elections. ${ }^{6}$ Anecdotal evidence also suggests that Pinochet's wife was responsible for many appointments, sometimes removing a mayor because he

\footnotetext{
${ }^{5}$ Examples of these social programs include the Minimum Employment Program implemented in 1975 (PEM) and the Occupation Program for Head of Households (POJH) implemented in 1982.

${ }^{6}$ Examples include the appointed mayors of Pudahuel municipality in the 1985-1989 period and La Cisterna municipality in the 1989-1992 period. Both mayors were members of right-wing parties, went on to win seats in the Congress representing the same local areas and remain in power until today.
} 
was not helping with CEMA-Chile, the organization of housewives that she led (Farfán and Vega, 2009), or because she felt that a mayor or his wife threatened her power, and sometimes rewarding people by appointing them as mayors of municipalities nearby large cities (Matus, 2014).

As stated in the Constitution, a referendum was held in October 1988 to determine whether Augusto Pinochet would remain in power for the following eight years. Pinochet lost with $44 \%$ of the vote and the transition to democracy began. The opposition candidate Patricio Aylwin won the subsequent presidential election in 1989 running with (among others) a proposal to "democratize municipalities." At the time, the opposition and the regime could not agree about what to do with local governments, and a final agreement to democratically elect mayors and councils only happened during the second year post-dictatorship. The first attempt came from President Patricio Aylwin, who in May 1990 proposed to hold local elections but the right-wing coalition expressed their discontent with the proposal because it could "weakened the institutional stability" (La Tercera, May 1990). A new proposal was sent in May 1991 which ended up being approved by right-wing parties in August 1991 (Díaz and Maturana, 1994; Mardones, 2006).

\subsection{The 1992 local election}

The second part of the empirical analysis exploits the transitory electoral rules in the 1992 local election to estimate the causal effect of electing dictatorship mayors on the performance of local governments. We now explain these peculiarities with some detail. It is important to emphasize that these rules were the result of negotiations across several political parties.

Law N. 19097 enacted in November 1991 established that a municipality was to be ruled by a mayor and a council democratically elected in local elections to be held in June 1992. However, in this election voters elected councilors instead of mayors. Councilors were to be elected using a D'Hondt method and the electoral rule for mayors was as follows: if a candidate obtained more than $35 \%$ of the votes and was part of the most voted list, then he or she became the mayor for the 1992-1996 period. ${ }^{7}$ If one of these requirements was not met, then the council elected the mayor

\footnotetext{
${ }^{7}$ Lists were groups of political parties and were registered before election day. There were six lists in the 1992 election: Concertación por la Democracia (list A) - composed by six parties - Communist Party (list B), Liberal Party (list C), Participación y Progreso (list D) - composed by three parties - Unión de Centro Centro (list E), and
} 
using a simple majority rule. ${ }^{8}$ Municipalities with less than 70 thousand registered voters elected 6 councilors, between 70 and 150 thousand elected 8, and those with more than 150 thousand elected 10. Term limits were only introduced in 2020 - two reelections, i.e. three terms or 12 years - and several mayors were in office for the whole period between 1992 and 2020.

The winner of this local election was the left-wing coalition Concertación por la Democracia with $53 \%$ of the vote. They elected 266 mayors and 1159 of 2076 councilors. The runner-up was the right-wing coalition with $30 \%$ of the vote, 62 mayors, and 756 councilors. The electoral rule together with the even number of councilors resulted in two mayors elected by the council among 84 races. In these cases the two elected mayors split the period in two terms of two years with a random order of incumbency. A total of 50 mayors obtained more than $35 \%$ of votes and were part of the most voted list and hence were directly elected as mayors for the 1992-1996 period. Of these mayors, 29 were from the left-wing coalition and 21 from the right-wing coalition, with the Christian Democrats being the party with the most mayors (18).

The rules to elect mayors were transitory and thus changed for the 1996 local elections. The most important change was that, if the most voted candidate was not part of the most voted list, then the most voted candidate from the most voted list was elected mayor. From 2004 onwards mayors and councilors were elected using a simple majority rule in separate ballots.

\section{Data construction}

This section explains how we gathered information about dictatorship mayors, how we constructed local spending measures, and provides descriptive statistics.

\subsection{Administrative sources}

We constructed two main datasets. The first contains the names of all mayors appointed by Pinochet since 1973. To the best of our knowledge this is the first time all names have been

Independent (list I).

${ }^{8}$ This electoral rule favored the Christian Democrats, a party in the center of the political spectrum but aligned with the left-wing coalition during the transition to democracy. Figure A.1 shows that a simple majority rule would have lead to more dictatorship mayors being elected (18\% instead of $12 \%)$. 
gathered in a single dataset. To construct these data, we collected the universe of official records on mayors' appointments from the Ministry of the Interior. Each time a mayor was appointed by Pinochet a decree was created with the full name of the mayor, the first date of the mandate, and the name of the municipality. In the few cases without information, we contacted municipalities directly to fill the gaps. We converted this information into a panel dataset of municipalities observed annually with the names of dictatorship mayors in each year. We observe 1,104 unique individuals serving as mayors in approximately 6,500 municipality-year positions.

The second dataset measures local spending annually during the dictatorship period using two sources. First, we digitized information about local projects implemented in the period from 1979 until 1996. We collected this information from annual reports produced by the Ministry of Housing and Urbanization. Examples of these projects include health infrastructure, paving, lighting, sewerage, fire stations, sport courts, and social housing, among others. We observe the exact dates of implementation, the municipality where the project took place, and the associated financial cost. Second, we digitized the revenues and spending of municipalities from annual reports collected by the General Accounting Office, available from 1985 onwards. Throughout the analysis we refer to the former measure as "local spending" and to the latter as "municipal spending."

We complemented this information with other administrative data. We use electoral data for local and presidential elections which we gather directly from the Electoral Service after 1988 and digitized from their administrative records before that year. We identified dictatorship mayors in the list of 6,500 candidates in the first local election in 1992 using a supervised probabilistic record matching algorithm. In particular, this procedure uses letters in full names - i.e. one or two given names and two family names - to assign a probability that pairs of full names correspond to the same individual. When the match was imperfect, we checked high probability cases manually. We found 246 dictatorship mayors running. We also use data measuring the number of victims of state repression by municipality, information collected by the National Commission on Truth and Reconciliation and the National Commission on Political Imprisonment and Torture (a.k.a. Valech and Rettig reports) and also used by Bautista et al. (2020). When studying the performance of mayors in democracy we use additional data from the General Accounting Office and the biennial 
CASEN surveys. Table A.1 presents descriptive statistics for some of these additional data.

\subsection{Descriptive statistics}

The data we constructed allow us to characterize the patterns behind appointments of mayors during the Pinochet dictatorship in an unusually rich way. Table 1 presents some descriptive statistics. The average municipality had three mayors during the dictatorship and mayors stayed in power for an average of four years. Yet some mayors remained in office for less than one year and some for the entire period of dictatorship. Panel (a) in Figure 2 shows the number of new appointments per year from 1968 until 1999, where we can clearly see the disruption after the 1973 coup. On average the dictatorship replaced 10-20\% of mayors each year. Panel (b) in the same figure shows the number of dictatorship mayors elected in local elections after the transition to democracy.

The drivers behind new appointments are poorly understood but anecdotal evidence suggest that they did not respond to changes in performance. The panels in Figure 3 provide suggestive evidence of this being the case. These panels show the correlation between the percentage of new appointments per municipality in a given periods (e.g. 1983-1985) as a function of variables that could have revealed the ability or performance of mayors. These figures reveal that the percentage of new appointments was unrelated to the intensity of protests in 1983-1984, to the intensity of one of the largest earthquakes ever recorded in 1985, to the local performance of mayors as measured by municipal deficits, and to the local implementation of repression during the 1973-1976 period. ${ }^{9}$ These patterns suggest that mayors were not removed because of their performance.

Panel (b) in Table 1 presents descriptive statistics for municipal revenues, municipal spending, and local spending at the municipality level. Figure 4 presents time variation in local spending as measured by the total number of projects and their monetary cost in the period 1979-1992. Two noticeable patterns emerge. First, the effect of the 1982-83 economic crisis can be seen by looking at the monetary resources invested during those years. Second, there is a significant increase of approximately 50\% in local spending in 1989. This year is somewhat unique because Pinochet

\footnotetext{
${ }^{9}$ Data for the intensity of the 1985 earthquake at the local level comes from the National Office of Emergency of the Interior Ministry (ONEMI). Protest data comes from annual reports produced by the Vicariate of Solidarity, a human rights organization operating during the dictatorship.
} 
knew that he would be leaving power and the new opposition coalition was going to take office in March 1990. Pinochet also had full control of monetary resources and could have implemented local projects at discretion. As we argue, both features imply that this is the ideal scenario for the dictatorship to attempt to retain some of their political power by increasing spending in local projects in order to gain support before the next election.

\section{Dictatorship mayors in the first local election}

This section shows that the dictatorship mayors who ran in the 1992 election obtained more votes than other candidates. We also show that this vote premium can be explained by an incumbency advantage and local spending before the transition to democracy.

\subsection{The vote premium of dictatorship mayors}

To estimate the differential electoral performance of dictatorship mayors in the 1992 local election when compared to other candidates, we estimate the following regression equation:

$$
V_{i j c}=\beta \cdot \text { Dictatorship mayor }{ }_{i}+\phi_{j}+\phi_{c}+\varepsilon_{i j c}
$$

where $V_{i j c}$ is the vote share of candidate $i$, affiliated to political party $j$, and running in municipality $c$. The main variable of interest is Dictatorship mayor $_{i}$, an indicator that takes the value of one for candidates who were appointed mayors during the dictatorship period. In addition, parameters $\phi_{j}$ and $\phi_{c}$ represent fixed effects by political party and municipality respectively, and we allow the error term $\varepsilon_{i j c}$ to be arbitrarily correlated within municipalities. There are 333 local elections in our data and 13 political parties. The parameter of interest is $\beta$ and measures the average differential vote share obtained by dictatorship mayors within municipalities and parties. ${ }^{10}$

The group of dictatorship mayors who decided to run for office might have been different in unobservable dimensions that were valued by voters and this could lead to bias in the $\beta$ coefficient.

\footnotetext{
${ }^{10}$ Dictatorship mayors ran under the umbrella of different right-wing parties or as independent candidates. This empirical fact allows us to separately estimate the vote premium associated to being a dictatorship mayor $(\beta)$ from the premium of being associated to a specific political party $\left(\phi_{j}\right)$.
} 
For instance, if the dictatorship mayors (or the citizens) with the highest probability of winning decided to run, then the coefficient on incumbents will be upward (downward) biased. Table 2 shows that those who ran were in office for more years and held office after 1983. In contrast, local spending during the dictatorship and transition periods, the intensity of state repression, the intensity of the 1983-84 protests, the vote share against Pinochet in the 1988 referendum (NO vote share), and the vote share for the opposition candidate (Aylwin) in the 1989 presidential election, all have little predictive power on the individual decision to run. ${ }^{11}$ We interpret this analysis as mayors unexpectedly facing the possibility of surviving the political transition when they were in office. The empirical patterns are inconsistent with a selection of candidates from the pool of all dictatorship mayors, e.g. a selection of dictatorship mayors in municipalities with high support for Pinochet. Unfortunately, the dearth in data precludes us from a full attempt to model the decision of becoming a candidate using other individual characteristics such as education or age. Thus, we highlight that our $\beta$ estimate has to be interpreted as causal with some caution.

Column 1 in Table 3 presents estimates of equation (1) without the inclusion of fixed effects, column 2 adds municipality fixed effects, and column 3 adds political party fixed effects. The importance of fixed effects is evident from the increase in model fit across columns. For reference, the average candidate obtained $5.1 \%$ of votes in a municipality, there were 246 dictatorship mayors running, the average municipality had 19 candidates competing, and there was at least one dictatorship mayor as candidate in 196 races (59\% of races).

The results indicate that dictatorship mayors obtained 9 percentage points higher vote share than other candidates. Consequently, Table A.3 in the appendix shows that they were 18 percentage points more likely to win the election, a substantial increase from a base of $7 \%$. Table A.4 shows that all these results are robust to the inclusion of the following more flexible two-way fixed effects: (i) political party by region, and (ii) political party by province. Finally, to assess the robustness of results to the inference method, we also implemented a randomization inference procedure

\footnotetext{
${ }^{11}$ For each of the 1,100 dictatorship mayors in the data we assign municipality characteristics from the municipality where they held office. In the few cases in which a mayor held office in more than one municipality, we assign the characteristics of the last one. Moreover, the analysis in Table A.2 shows that local spending appears unlikely to have been strategically allocated as it is not robustly related to vote shares and state repression. Figure A.4 shows that the share of incumbent mayors who decided to run in 1992 was higher towards the end of the dictatorship.
} 
which does not depend on the asymptotic normality of estimates (Young, 2019). In particular, we randomized being a dictatorship mayor within a municipality 1,000 times and estimated equation (1) each time to perform randomization inference. Reassuringly, our estimate is above the $99 \%$ of randomized estimates. Below we explore the causes behind this vote premium.

\subsection{The role of incumbency}

The evidence so far suggests that dictatorship mayors obtained a 9 percentage points higher vote share than other candidates in the same municipality and other candidates in the same political party. Why were citizens voting relatively more for mayors previously appointed by Pinochet? Perhaps the most intuitive explanation for this vote premium is the existence of an incumbency advantage. More precisely, the last wave of dictatorship mayors before the 1992 election could have had an advantage simply because he or she was the incumbent mayor, a robust empirical finding across many countries and time periods (e.g. Lee 2008). ${ }^{12}$

In an attempt to capture the essence of the incumbency that has been studied in the literature, we say that a dictatorship mayor was an incumbent candidate in the 1992 local elections if she or he met the following requirements: (1) he or she was a mayor appointed by the Pinochet dictatorship, (2) held office after the 1988 referendum, and (3) decided to run in the same municipality where he or she held office. Using this definition we calculate that 117 of the 246 dictatorship mayors running in the 1992 local election were incumbent candidates and thus the remaining 129 dictatorship mayors were non-incumbent candidates.

To test for the role of incumbency in the 1992 election, we constructed an indicator that takes the value of one for dictatorship mayors who were the sitting incumbent. Then, we augmented equation (1) to include this variable as an additional predictor of vote shares. Column 4 in Table 3 presents the estimation result. The coefficient for dictatorship mayors decreases from 9 to 6.5 percentage points and the coefficient for incumbents is 6 percentage points $(p$-value $<0.05)$. This estimate constitutes suggestive evidence of an incumbency advantage among dictatorship mayors.

\footnotetext{
${ }^{12}$ Additional examples include Fowler and Hall (2014); Erikson and Titiunik (2015); Fiva and Smith (2018). There is less clarity about what explains the incumbency effect. Potential mechanisms include information about incumbents and a positive valuation of the political experience obtained in office.
} 
Because the vote premium was 9 percentage points and dictatorship mayors who were not incumbents obtained 6 percentage points of premium, we conclude that an incumbency advantage can explain at most one-third of the vote premium of dictatorship mayors. The next section argues that part of the remaining two-thirds can be explained by an increase in local spending.

The incumbency advantage gained by dictatorship mayors appears to be similar to the wellknown "incumbency advantage" obtained by elected mayors in democracy. We reach this tentative conclusion after an empirical analysis of the second local election held in democracy in 1996, where we observe 38 dictatorship and 317 non-dictatorship incumbent mayors running for reelection. Table 4 presents estimates of the same equation (1) but now using data from the 1996 elections. ${ }^{13}$ The results reveal that the incumbency advantage seems to apply to both dictatorship and non-dictatorship mayors equally. Columns 1 through 4 use the vote shares of all candidates in 1996 as dependent variable. Our preferred specifications are in columns 5-6, where we restrict attention to municipalities where the winners and runner-ups in the 1992 election decided to run. ${ }^{14}$ These columns reveal an incumbency advantage of 13 percentage points for incumbent mayors, a number that is similar in the sub-sample of incumbent mayors who held office in dictatorship.

\subsection{The role of local spending}

Before the transition to democracy, the dictatorship could have decided to increase their spending to maximize the probability of their mayors being elected in the upcoming elections. Descriptive statistics in the previous section suggest that local spending increased after the announcement of the transition in October 1988. To test for this explanation we augment equation (1) to allow for a

\footnotetext{
${ }^{13}$ Municipality-level characteristics such as the margin of victory are absorbed by the fixed effects $\phi_{c}$. Note that 123 dictatorship mayors were non-incumbent candidates and a few municipalities had two mayors, hence the number of incumbent mayors running is larger than the number of municipalities. A caveat with this analysis is that we are comparing dictatorship mayors with more than one period in office (1992-1996 plus the dictatorship period) with non-dictatorship mayors who held office for one period (1992-1996).

${ }^{14}$ There were 260 incumbent mayors running in this sub-sample, 27 who were dictatorship mayors, and 40 dictatorship mayors who were runner-ups in 1992. The results are again robust to the inclusion fixed effects by party-region and party-province. See Table A.5 for details.
} 
differential effect of local spending in different political periods. In particular, we estimate:

$$
\left.V_{i j c}=\beta \cdot{\text { Dict } \text { mayor }_{i}+\sum_{p} \gamma_{p} \cdot(\text { Dict mayor }}_{i} \times \text { Local spending }_{c}^{p}\right)+\phi_{j}+\phi_{c}+\varepsilon_{i j c}
$$

where Local spending ${ }_{c}^{p}$ is local spending in projects or municipal spending in municipality $c$ during period $p$. We call "dictatorship" to the period before October 1988, "transition" to the period between October 1988 and March 1990, and "democracy" to the period between March 1990 and June 1992. The remaining variables are defined in the same way as before.

The coefficients of interest are $\gamma_{D I C T}, \gamma_{T R A N}, \gamma_{D E M}$ and measure the empirical association between spending in different political periods and the vote share of dictatorship mayors in the 1992 election. We measure local spending by the number of local projects and their financial cost separately, and municipal spending using monetary units. The former were relatively visible projects where the dictatorship had decision power and the latter is related to the day-to-day functioning of local governments. In addition, we follow previous literature and use the logarithm of spending per capita (Corvalán et al., 2018; Lara and Toro, 2019; Livert et al., 2019).

If the dictatorship was successful at gaining support through public spending before the transition to democracy, then we expect that $\widehat{\gamma}_{T R A N}>0$ and $\widehat{\gamma}_{T R A N}>\widehat{\gamma}_{D I C T}, \widehat{\gamma}_{D E M}$. To be clear, we expect that $\widehat{\gamma}_{T R A N}>\widehat{\gamma}_{D E M}$ because we assume voters knew which coalition was doing the spending and could associate it with old-regime candidates from those coalitions. In addition, we hypothesize that $\widehat{\gamma}_{T R A N}>\widehat{\gamma}_{D I C T}$ for two reasons. First, spending during the transition could have been targeted precisely for political purposes. Second, local spending that is closer to the local election should have a higher impact on vote shares simply because of what is known as "recency bias," i.e. the tendency of voters to value recent information more than older information (Berry and Howell, 2007). In any case, whether $\widehat{\gamma}_{T R A N}>\widehat{\gamma}_{D I C T}$ is ultimately an empirical question.

Table 5 presents estimates of equation (2). Column 1 uses spending per capita as independent variable, column 2 the total number of projects per capita, and column 3 municipal spending per capita. Overall, the results are consistent with the hypothesis that the Pinochet regime was successful at winning political support via public spending in the transition period. To facilitate the 
interpretation of coefficients we have standardized local and municipal spending. A one standard deviation increase in local spending during the transition period is associated to an increase of 2-4 percentage points in the vote share of dictatorship mayors (columns 2 and 3). In contrast, local spending in other periods has little statistical relationship with vote shares in the 1992 election and the point estimate is also of significantly lower magnitude. Moreover, changes in municipal spending are also not statistically associated with vote shares. Finally, in the appendix we also show that these results are unlikely to have been affected by the intensity of state repression. In particular, Table A.6 presents results from an extended version of equation (2) in which we also include the number of victims of state repression per 1,000 inhabitants interacted by the indicator for dictatorship mayors. The point estimates indicate that, if anything, repression positively affected dictatorship mayors, and the importance of spending during the transition period remains similar.

\subsection{Discussion}

If both an incumbency advantage and the extent of local spending can explain the vote premium of dictatorship mayors, then we should observe higher vote shares for both incumbent and nonincumbent mayors regardless of the amount of local spending. To test for this implication of our argument, we augment equation (2) by separating the dictatorship mayor indicator in two indicators, one for incumbents and another one for non-incumbent dictatorship mayors. The results

in Table A.7 show that indeed both incumbent and non-incumbents obtained a vote premium in the 1992 local election, with the former almost twice the size of the latter, i.e. 12.47 vs. 6.35 percentage points. Interestingly, this table also provides suggestive evidence of incumbent mayors benefitting the most from local spending: the interaction with local spending during the transition period is larger among incumbent mayors (3.79 vs. 1.87 percentage points, see column 1).

Taken together, the empirical patterns in this section suggest that both an incumbency advantage and local spending during the transition period can partially explain the vote premium of dictatorship mayors in the 1992 local election. However, we acknowledge that there might be additional mechanisms explaining this persistence of authoritarian elites which we cannot fully identify with our data. What were the economic and political consequences of dictatorship mayors 
making their way into the new democratic era? The following section offers an empirical strategy to estimate the political and economic consequences of persistent dictatorship mayors.

\section{The legacies of dictatorship mayors}

What are the political legacies of dictatorship mayors? Do they perform better or worse than other mayors? These are key questions that speak directly to the functioning of young democracies with a recent authoritarian history. In this section, we address these questions by evaluating the legacies of dictatorship mayors on local and presidential elections, and also on the performance of local governments after democratization.

\subsection{Quasi-random variation in council composition}

Dictatorship mayors were not randomly elected in the 1992 election. Therefore, a simple comparison of outcomes across municipalities ruled and not ruled by them is unlikely to reveal the causal effect of their mandate. However, transitory electoral rules in this election help us to approximate a natural experiment in which dictatorship mayors were quasi-randomly elected in a subset of municipalities. In particular, we use the fact that the most-voted candidates within a municipality were elected as councilors and these councilors elected mayors using a simple majority rule. Voters directly elected the mayor in the remaining municipalities. In the municipalities we study, the political composition of the council was key since the coalition with the majority of councilors essentially elected the major. The majority in the council was, however, sometimes reached by quasi-random variation in voting patterns that we now describe.

To illustrate our argument, Table 6 considers voting scenarios in a municipality with six councilors. ${ }^{15}$ In some municipalities, the five or six most voted candidates were from the same coalition and elected a mayor from their coalition (cases L1, L2, R1, and R2). Something similar happened if the four most voted candidates and the 6th/7th candidates were from the same coalition. However, note that in a subset of elections the order of the 6 th/7th candidates had a disproportionate

\footnotetext{
${ }^{15}$ As discussed in section 2 the size of the council could have also been eight or ten in some municipalities depending on population, but our argument extends naturally to those cases.
} 
impact on the elected mayor (cases L3-L5 and R3-R5). There are two types of cases: (i) a coalition had a majority because of the order of the 6th/7th candidates (cases L3 and R3), this is, a different order of these candidates would have made them lose the majority; and (ii) coalitions were equally represented but a different order of the 6th/7th candidates would have caused a majority (cases L4-L5 and R4-R5). Therefore, the quasi-random variation in council majority is embedded in the order of these marginal candidates in a subset of races we call "quasi-experimental sample."16

Operationally, we select the "quasi-experimental" sample of municipalities with the previous type of variation following four steps. First, we begin with the 333 municipalities with a local election in 1992. Second, we restrict attention to the 284 municipalities where the council had to elect the mayor because no candidate obtained more than $35 \%$ of the vote and was part of the most voted list (see section 2.2). Third, we order candidates by their vote shares in each municipality and restrict attention to races with 2, 3, or 4 left-wing candidates among the six most voted. ${ }^{17}$ And fourth, we keep in the "quasi-experimental" sample a total of 105 municipalities in which the sixth and seventh most voted candidates were from different coalitions ( $\mathrm{L} / \mathrm{R}$ or $\mathrm{R} / \mathrm{L})$.

In this quasi-experimental sample the order of the marginal candidates affected which coalition had the majority in the council. The councils that marginally obtained a left-wing majority never elected a dictatorship mayor, but had the order of the marginal candidates been different, the council could have elected a dictatorship mayor. The vote difference between the marginal candidates in this sample was on average 1.2 percentage points. ${ }^{18}$ More precisely, we estimate the equation:

$$
Y_{c t}=\beta \cdot \text { Dict mayor } \text { m,1992 }+\gamma X_{c, 1992}+\phi_{t}+\varepsilon_{c t}
$$

where $Y_{c t}$ is an outcome of interest in municipality $c$ measured in year $t>1992$ and Dict mayor ${ }_{c, 1992}$ is an indicator that equals one if a dictatorship mayor was elected in municipality $c$ in 1992, and

\footnotetext{
${ }^{16}$ Please note that the order of the 6th/7th candidates had a probabilistic (instead of a deterministic) impact in the majority of a coalition because of the D'Hondt method employed to select councilors.

${ }^{17}$ Again, the argument extends naturally to municipalities electing eight (ten) councilors: we restrict attention to municipalities with 3-5 (4-6) left-wing candidates among the eight (ten) most voted.

${ }^{18}$ The standard deviation of the vote difference between marginal candidates is 1.1 and the maximum difference is 7.5 percentage points. In the appendix we show that results are robust to focus on the sample of municipalities with vote difference lower than 5 and 2.5 percentage points between the marginal candidates.
} 
zero otherwise. The vector $X_{c, 1992}$ includes the voting margin between the marginal candidates and indicators for the size of the council. We allow the error term $\varepsilon_{c t}$ to be correlated within municipalities and include year fixed effects $\phi_{t}$.

As discussed, many omitted variables could explain the election of a dictatorship mayor and the subsequent performance of a municipality. To overcome this endogeneity problem, we estimate equation (3) using a two-stage least squares (2SLS) procedure based on the marginal candidates. In particular, the first stage equation in our empirical strategy is given by:

$$
\text { Dict mayor }_{c, 1992}=\pi \cdot \text { Left-wing majority }_{c, 1992}+\tau X_{c, 1992}+v_{c}
$$

where all variables are defined as before and Left-wing majority $y_{c, 1992}$ is the exogenous instrument which takes the value of one if there was a left-wing majority in the council and zero otherwise within the quasi-experimental sample. Panel A in Table 7 shows that when there was a left-wing majority in a council precisely because of the order of the marginal candidates, the probability of electing a dictatorship mayor decreased by 24 percentage points ( $p$-value $<0.01)$. In fact, dictatorship mayors were never elected when the left-wing coalition had a majority in the council.

If our research design is valid, then municipalities with different council composition - due to the quasi-random order of the marginal candidates in the quasi-experimental sample - should look similar before the council had to elect the mayor. Reassuringly, panels B and C in Table 7 show that this seems to be in fact the case. Column 4 shows the average difference across municipalities with and without a left-wing majority in the sub-sample of interest. Column 5 is our preferred test of balance and shows the same differences after adjusting for the size of the council. Reassuringly, municipalities with different council composition were similar in terms of their political support for left or right-wing parties in all relevant elections between 1970 and 1989. These municipalities were also similar in terms of the electoral competition in the 1992 local election: both have similar share of right-wing candidates, independent candidates, and female candidates, and also a similar number of candidates running for office. Moreover, these municipalities were also similar in terms of local and municipal spending during the dictatorship and transition periods, had similar 
geographic location, similar number of houses per capita in 1970, similar percentage of women in 1970, similar discontent with the dictatorship as measured by the 1983-84 protests, and were similarly affected by state repression. In sum, this table suggests that the left-wing majority was quasi-random in this subset of races.

\subsection{The political legacies}

We measure the political legacies of dictatorship mayors using the vote shares for right-wing candidates in local and presidential elections, an indicator for right-wing candidates being elected, and the share of right-wing councilors elected. Right-wing political parties worked in coalition with the dictatorship and many right-wing candidates collaborated closely with the Augusto Pinochet regime (Huneeus, 2006). ${ }^{19}$ To increase the power of our analysis, we stack all elections after the year 1993. Thus, for each municipality we observe vote shares in six local elections (1996, 2000, 2004, 2008, 2012, 2016) and six presidential elections (1993, 1999, 2005, 2009, 2013, 2017). Moreover, to emphasize the importance of focusing on the subset of municipalities where the composition of the council was determined quasi-randomly, Table 8 presents results using all municipalities (columns 1-2) and the subset of 105 municipalities where the order of marginal candidates had a disproportionate impact on the majority in the council (columns 3-8).

Panel A in Table 8 presents two-stage least squares of equation (3) and Panel B displays the first-stage and the corresponding Kleibergen-Paap rk Wald $F$-statistic that measures the statistical strength of the instrument. Reassuringly, these $F$-statistics are always larger than 12 , ameliorating concerns about biases associated with weak instruments (Stock and Yogo, 2005). Columns 1 and 2 show that dictatorship mayors are associated with a higher vote share for right-wing candidates in subsequent local and presidential elections. This correlation is unsurprising given that these mayors were explicitly or implicitly linked to the right-wing coalition. Columns 3 and 5 present estimates using our econometric strategy and thus the causal impact of dictatorship mayors on right-wing vote shares. These estimates suggest that, when a dictatorship mayor was (randomly) elected in 1992, the vote share of right-wing candidates in democracy increased by approximately

\footnotetext{
${ }^{19}$ Tables A.8 and A.9 provide more details about how we grouped candidates and coalitions in left- and right-wing using administrative data from the Electoral Service office.
} 
19 percentage points (pp.) in local elections and by approximately $10 \mathrm{pp}$. in presidential elections. These are economically meaningful estimates similar in magnitude to prominent estimates of incumbency advantage in the political economy literature (e.g. Lee 2008). Columns 4 and 6 repeat this empirical specification but drops dictatorship mayors from the quasi-experimental sample and uses as treatment variable an indicator for right-wing mayors elected by the council. The results indicate somewhat smaller impacts on subsequent right-wing vote shares, highlighting the importance of dictatorship mayors beyond their party of affiliation.

Two remarks are worth mentioning. First, dictatorship mayors do not appear to be associated with higher or lower electoral competition in democracy. Table A.10 looks at the margin of victory, number of candidates, and an index of vote concentration and we fail to find consistent evidence of differential competition. Second, an analysis of local elections by year reveals a relatively strong effect on right-wing vote shares in 1996 which becomes smaller in the following years (Table A.11). In contrast, presidential elections reveal a somewhat similar effect across years with a relatively larger impact in 2017 (Table A.12). We suspect that time-varying events were likely to have made Pinochet and his allies more or less salient to voters at different points in time. Some prominent examples include the arrest of Pinochet in 1998, his death in 2006, and the waves of protests against his legacies in 2006 and 2011. Similarly, changes to political institutions in 2012 (i.e. voluntary voting) and 2015 (i.e. electoral reform) could also potentially help to explain these patterns.

What was the impact of dictatorship mayors on the selection of politicians? Columns 7 and 8 in Table 8 examine local elections and show that dictatorship mayors affected the selection of right-wing councilors. We restrict attention to 1996 and 200 because of the electoral rules to select politicians. In these elections, the average municipality in the quasi-experimental sample had 13 candidates in a single ballot running for seats in the council and to be the mayor, i.e. leader of the council. From 2004 onwards candidates for mayor and councilor positions ran in separate ballots. Column 7 shows that the probability of electing a right-wing mayor in 1996 and 2000 was 23 pp. higher in locations ruled by a dictatorship mayor in the period 1992-1996, but the coefficient is imprecisely estimated and we cannot reject a null impact. Column 8 shows that dictatorship 
mayors increased the share of right-wing councilors elected by 18 percentage points from a base of 20 percent ( $p$-value $<0.05$ ). This is, the average number of right-wing councilors in 1996 and 2000 increased from 2.5 to 4.5 due to the election of a dictatorship mayor in 1992.

The impact of dictatorship mayors on vote shares for right-wing candidates after the transition to democracy is a robust finding. Table A.13 shows that the estimates are similar when we drop the few municipalities where the vote difference between marginal candidates was larger than 5 percentage points (columns 1-2). Moreover, columns 3-4 show that the estimates remain similar when we only employ the sub-sample of municipalities where this vote difference was lower than 2.5 percentage points. Finally, Table A.14 shows that the results are similar if we include as additional controls the square of the vote difference between marginal candidates in and out of the council and a large set of county characteristics from panels B and C of Table 7. All in all, we conclude that dictatorship mayors had a positive impact on the selection of right-wing politicians.

\subsection{The performance of dictatorship mayors}

In contrast to previous results, we fail to find significant and consistent differences in the performance of dictatorship mayors when compared to other mayors in democracy. To measure the performance of mayors, Table 9 looks at the ratio of municipal expenditures to revenues annually in the period 1993-1996 (i.e. budget deficit, column 1), and local projects in the same years (columns 2-3). When we examine these three outcomes we again stack all municipalities to increase the power of the analysis, thus creating a sample of 411 municipality-year observations. In addition, we also study an indicator for misreporting municipal expenditures, available for 1996 and constructed by the General Accounting Office of Chile. Finally, we use the change in night lights between 1992 and 1996 as a measure of local development (Henderson et al., 2012) and the change in average wages as reported in the subsample of 46 municipalities with survey respondents in the 1992 and 1996 waves of the CASEN survey. Although we acknowledge none of these variables perfectly measures the performance of mayors, we believe that when taken as a whole they provide insights about their actions in office. Nevertheless, we highlight that there could be other unobserved dimensions of performance that are not captured by the outcomes we examine. 
Panel A in Table 9 presents results and panel B presents the corresponding first-stage. We cannot reject that municipalities ruled and not ruled by dictatorship mayors in the period 1993-1996 performed similarly. Moreover, the sign of coefficients is inconsistent across columns, sometimes suggesting that in municipalities with dictatorship mayors there was less corruption (column 4) and sometimes suggesting worse performance as measured by a higher budget deficit (column 1), fewer monetary resources invested in projects (column 2-3), lower growth in night lights (column 5 ), and a lower growth in wages (column 6). The confidence intervals of all of these estimates are also relatively large, preventing us from reaching a firm conclusion. Finally, the reader might worry about the role of the electoral cycle in driving these findings (Corvalán et al., 2018) and a potential difference in the type of projects implemented by dictatorship mayors. However, the results are similar when looking at years away from local elections (Table A.15) and subcategories of local projects (Table A.16). Taken together, we interpret these estimates as inconclusive about the performance of (elected) dictatorship mayors after the transition to democracy.

\section{Conclusion}

We have shown that mayors appointed by the Pinochet dictatorship in Chile obtained a vote premium in the first local election after the return to democracy. An incumbency advantage and an increase in local spending before the transition help to explain this premium. Because these mayors are associated to more votes for right-wing parties in democracy, these findings reveal new ways in which dictatorships can influence the functioning of young democracies.

The results in this paper suggest that policies limiting the participation of dictatorship politicians in elections in a new democracy have the potential to reduce the influence of the previous authoritarian regime. Even in the absence of an increase in local spending, the existence of an incumbency advantage implies that dictatorship politicians will always obtain relatively more votes than their competitors. When authoritarian regimes hold local elections, the competitiveness of these races and the representation of opposition parties can naturally affect whether the body of elected officials can or should participate in subsequent democratic elections.

Two limitations are important to mention in order to interpret the results in this study more 
broadly. First, besides local spending in projects there might be additional strategies used by incumbent dictatorships to preserve their political power. Examples include an improvement in the provision of police services, public education, public health, or any other state service more generally. An increase in projects could crowd-out some of these other services or could complement them. Second, some democratizations might be more abrupt than a democratization by election and, precisely because of it, the fastest transitions could restrict the ability of incumbent dictators to strategically act to transmit their political or economic power across regimes.

Finally, we believe this study opens new questions about the fate of dictatorship politicians after a democratization. In Chile many politicians started their careers by being appointed during the Pinochet regime and remain working in powerful positions in the public sector until today. Whether this type of public officials contribute to inefficiencies in the public sector or not needs to be better understood empirically. In addition, more work is necessary to understand if authoritarian regimes are able to allocate resources across municipalities efficiently or not. Uncontested political power might facilitate the extraction of rents but it might also allow accomplishing projects that might be more difficult to pursue when negotiating with others.

\section{References}

Acemoglu, D. (2008). Oligarchic versus democratic societies. Journal of the European Economic Association, 6(1):1-44.

Acemoglu, D. and Robinson, J. (2008). Persistence of power, elites, and institutions. American Economic Review, 98(1):267-293.

Acemoglu, D., Ticchi, D., and Vindigni, A. (2011). Emergence and persistence of inefficient states. Journal of the European Economic Association, 9(2):177-208.

Albertus, M. (2019). The fate of former autoritharian elites under democracy. Journal of Conflict Resolution, 63(3):727-759. 
Albertus, M. and Menaldo, V. (2014). Gaming democracy: Elite dominance during transition and the prospects for redistribution. British Journal of Political Science, 44(3):575-603.

Albertus, M. and Menaldo, V. (2018). Authoritarianism and the Elite Origins of Democracy. Cambridge University Press.

Aldunate, F., González, F., Prem, M., and Urzúa, F. (2020). Privatization and business groups: Evidence from the chicago boys in chile. Explorations in Economic History, 78:101355.

Bagues, M. and Esteve-Volart, B. (2016). Politicians' luck of the draw: Evidence from the Spanish christmas lottery. Journal of Political Economy, 124(5):1269-1294.

Bautista, M. A., González, F., Martínez, L., Muñoz, P., and Prem, M. (2020). The geography of dictatorship and opposition to autocracy. American Journal of Political Science.

Berman, E., Shapiro, J., and Felter, J. (2011). Can hearts and minds be bought? The economics of counterinsurgency in Iraq. Journal of Political Economy, 119(4):766-819.

Berry, C. and Howell, W. (2007). Accountability and local elections: rethinking retrospective voting. Journal of Politics, 69(3):844-858.

Besley, T. and Coate, S. (2003). Elected versus appointed regulators: Theory and evidence. Journal of the European Economic Association, 1(5):1176-1206.

Brownlee, J. (2007). Hereditary succession in modern autocracies. World Politics, 59(4):595-628.

Cavallo, A., Salazar, M., and Sepúlveda, O. (2011). La Historia Oculta del Régimen Militar: Memoria de una Época 1973-1988. Uqbar editores.

Chen, Y. and Yang, D. Y. (2019). The impact of media censorship: 1984 or brave new world? American Economic Review, 109(6):2294-2332.

Choi, S., Gulati, M., and Posner, E. (2010). Professionals or politicians: The uncertain empirical case for an elected rather than appointed judiciary. Journal of Law, Economics, and Organization, 26(2):290-336. 
Colonnelli, E., Prem, M., and Teso, E. (2020). Patronage and selection in public sector organizations. American Economic Review, 110(10):3071-99.

Corvalán, A., Cox, P., and Osorio, R. (2018). Indirect political budget cycles: Evidence from Chilean municipalities. Journal of Development Economics, 133:1-14.

Dal Bó, E., Dal Bó, P., and Snyder, J. (2009). Political dynasties. Review of Economic Studies, 76(1):115-142.

Dal Bó, E. and Finan, F. (2018). Progress and perspectives in the study of political selection. Annual Review of Economics, 10:541-75.

Díaz, J. and Maturana, C. (1994). Las elecciones municipales de 1992 en Chile. Revista de Derecho Político, (38):473-504.

Donaldson, D. (2018). Railroads of the Raj: Estimating the impact of transportation infraestructure. American Economic Review, 108(4):899-934.

Erikson, R. and Titiunik, R. (2015). Using regression discontinuity to uncover the personal incumbency advantage. Quarterly Journal of Political Science, 10(1):101-119.

Faber, B. (2014). Trade integration, market size, and industrialization: Evidence from China's national trunk highway system. Review of Economic Studies, 81(3):1046-1070.

Fafchamps, M. and Labonne, J. (2020). Family networks and distributive politics. Journal of the European Economic Association, 18(4):1697-1725.

Farfán, C. and Vega, F. (2009). La Familia. Historia Privada de los Pinochet. Random House Mondadori.

Ferraz, C., Finan, F., and Martinez-Bravo, M. (2020). Political power, elite control, and long-run development: Evidence from Brazil. Working Paper.

Fiva, J. H. and Smith, D. M. (2018). Political dynasties and the incumbency advantage in partycentered environments. American Political Science Review, 112(3):706-712. 
Fowler, A. and Hall, A. (2014). Disentangling the personal and partisan incumbency advantages: Evidence from close elections and term elections. Quarterly Journal of Political Science, 9(4):1142-1164.

Geddes, B., Wright, J., and Frantz, E. (2018). How Dictatorships Work: Power, Personalization, and Collapse. Cambridge University Press.

González, F. and Prem, M. (2020). Losing your dictator: Firms during political transition. Journal of Economic Growth, 25(2):227-257.

González, F., Prem, M., and Urzúa, F. (2020). The privatization origins of political corporations: Evidence from the Pinochet regime. Journal of Economic History, 80(2):417-456.

Henderson, J. V., Storeygard, A., and Weil, D. N. (2012). Measuring economic growth from outer space. American Economic Review, 102(2):994-1028.

Hessami, Z. (2018). Accountability and incentives of appointed and elected public officials. Review of Economics and Statistics, 100(1):51-64.

Honna, J. (2010). The legacy of the new order military in local politics. In Soeharto's New Order and Its Legacy: Essays in honour of Harold Crouch. ANU Press.

Hornbeck, R. and Donaldson, D. (2016). Railroads and American economic growth: A “market access" approach. Quarterly Journal of Economics, 131(2):799-858.

Huneeus, C. (2006). The Pinochet Regime. Lynne Rienner Publishers.

Huntington, S. (1991). The Third Wave. Norman: University of Oklahoma Press.

Labonne, J. (2013). The local electoral impacts of conditional cash transfers: Evidence from a field experiment. Journal of Development Economics, 104:73-88.

Lara, B. and Toro, S. (2019). Tactical Distribution in Local Funding: The Value of an Aligned Mayor. European Journal of Political Economy, 56:74-89. 
Lee, D. S. (2008). Randomized experiments from non-random selection in U.S. House elections. Journal of Econometrics, 142:675-697.

Levin, J. and Tadelis, S. (2010). Contracting for government services: Theory and evidence from U.S. cities. Journal of Industrial Economics, LVIII(3):507-541.

Linz, J. J. and Stepan, A. (1996). Problems of Democratic Transition and Consolidation: Southern Europe, South America, and Post-Communist Europe. Baltimore: Johns Hopkins University Press.

Livert, F., Gaínza, X., and na, J. A. (2019). Paving the electoral way: Urban infrastructure, partisan politics and civic engagement. World Development, 124:104628.

Manacorda, M., Miguel, E., and Vigorito, A. (2011). Government transfers and political support. American Economic Journal: Applied Economics, 3(3):1-28.

Mardones, R. (2006). Descentralización y transición en Chile. Revista de Ciencia Política, 26(1):3-24.

Martínez Bravo, M. (2014). The role of local officials in new democracies: Evidence from Indonesia. American Economic Review, 104(4):1244-87.

Martínez Bravo, M., Mukherjee, P., and Stegmann, A. (2017). The non-democratic roots of elite capture: Evidence from Soeharto mayors in Indonesia. Econometrica, 85(6):1991-2010.

Martínez Bravo, M., Padró-i-Miquel, G., Qian, N., and Yao, Y. (2020). The rise and fall of local elections in China: Evidence on the autocrat's trade-off. Working Paper.

Marx, B. (2018). Elections as incentives: Project completion and visibility in African politics. Working Paper.

Matus, A. (2014). Doña Lucía. Penguin Random House.

Michaels, G. (2008). The effect of trade on the demand for skill: Evidence from the interstate highway system. Review of Economics and Statistics, 90(4):683-701. 
Myerson, R. B. (2015). Moral hazard in high office and the dynamics of aristocracy. Econometrica, 83(6):2083-2126.

Nunn, N. (2020). The historical roots of economic development. Science, 367(6485):eaaz9986.

O’Donnell, G. and Schmitter, P. C. (1986). Transitions from Authoritarian Rule: Tentative Conclusions about Uncertain Democracies. The Johns Hopkins University Press.

Robinson, R. and Hadiz, V. (2004). Reorganizing Power in Indonesia: The Politics of Oligarchy in an Age of Markets. London: Routledge.

Stock, J. and Yogo, M. (2005). Testing for weak instruments in linear IV regression. In Identification and Inference for Econometric Models: Essays in Honor of Thomas Rothenberg, chapter 5, pages $80-108$.

Treisman, D. (2020). Democracy by mistake: How the errors of autocrats trigger transitions to freer government. American Political Science Review, 114(3):792-810.

Valdivia, V., Álvarez, R., and Donoso, K. (2012). La Alcadización de la Política. Los Municipios en la Dictadura Pinochetista. Santiago de Chile: LOM Ediciones.

Voigtländer, N. and Voth, H.-J. (2018). Highway to Hitler. Working Paper.

$\mathrm{Xu}, \mathrm{G}$. (2018). The costs of patronage: Evidence from the Briitish Empire. American Economic Review, 108(11):3170-3198.

Young, A. (2019). Channeling fisher: Randomization tests and the statistical insignificance of seemingly significant experimental results. Quarterly Journal of Economics, 134(2):557-598. 
Figure 1: Timeline of main political events

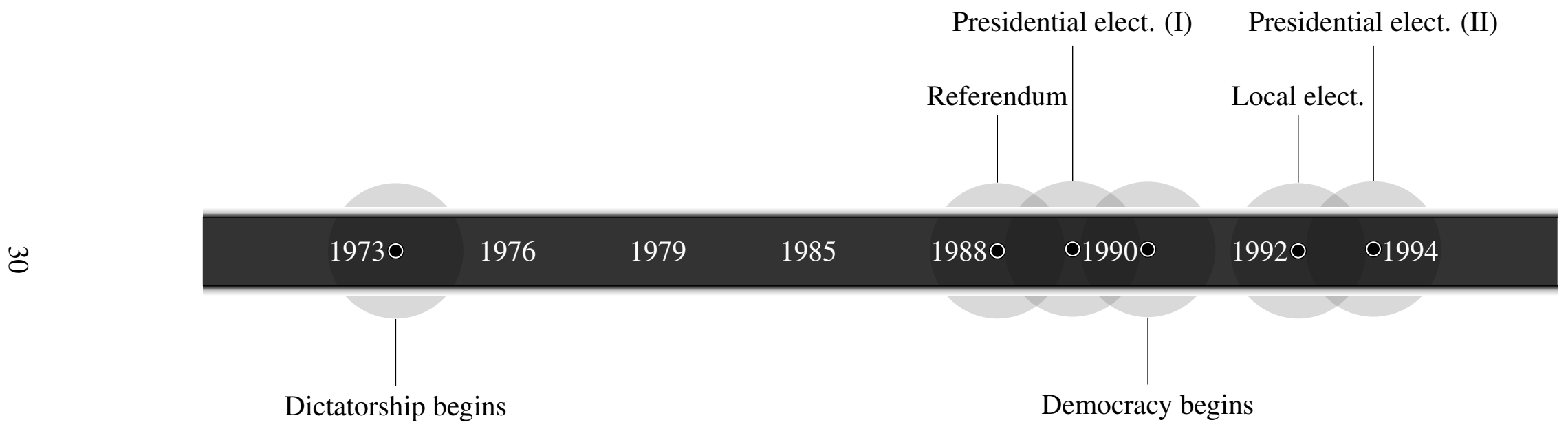

Notes: Timeline of the main political events for the purposes of the analysis in the paper. We call "transition" to the period between the 1988 referendum in October ("Referendum") and the time when the first democratic government after dictatorship took office (March 1990, "Democracy begins"). The first democratic government goes from March 1990 until March 1994. The first local election in democracy took place in June 1992. The second presidential election took place in December 1993 ("Presidential elect. (II)"). 
Figure 2: Appointments and persistence of dictatorship mayors

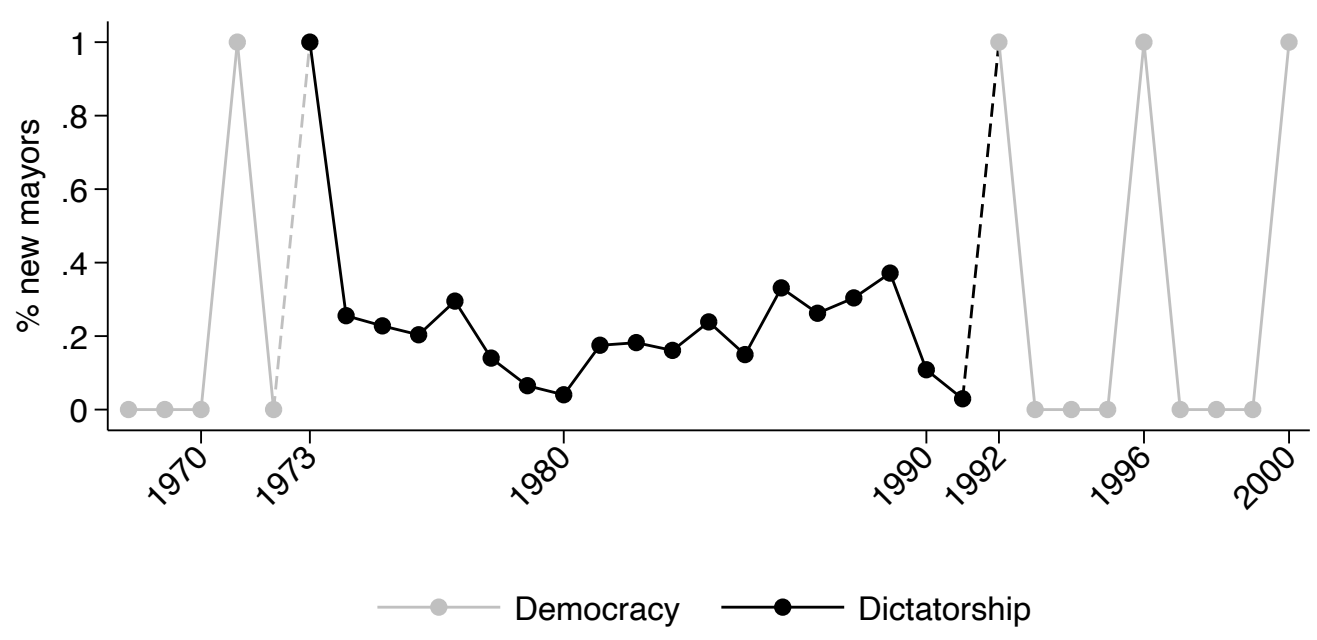

(a) The appointments of mayors in dictatorship and democracy

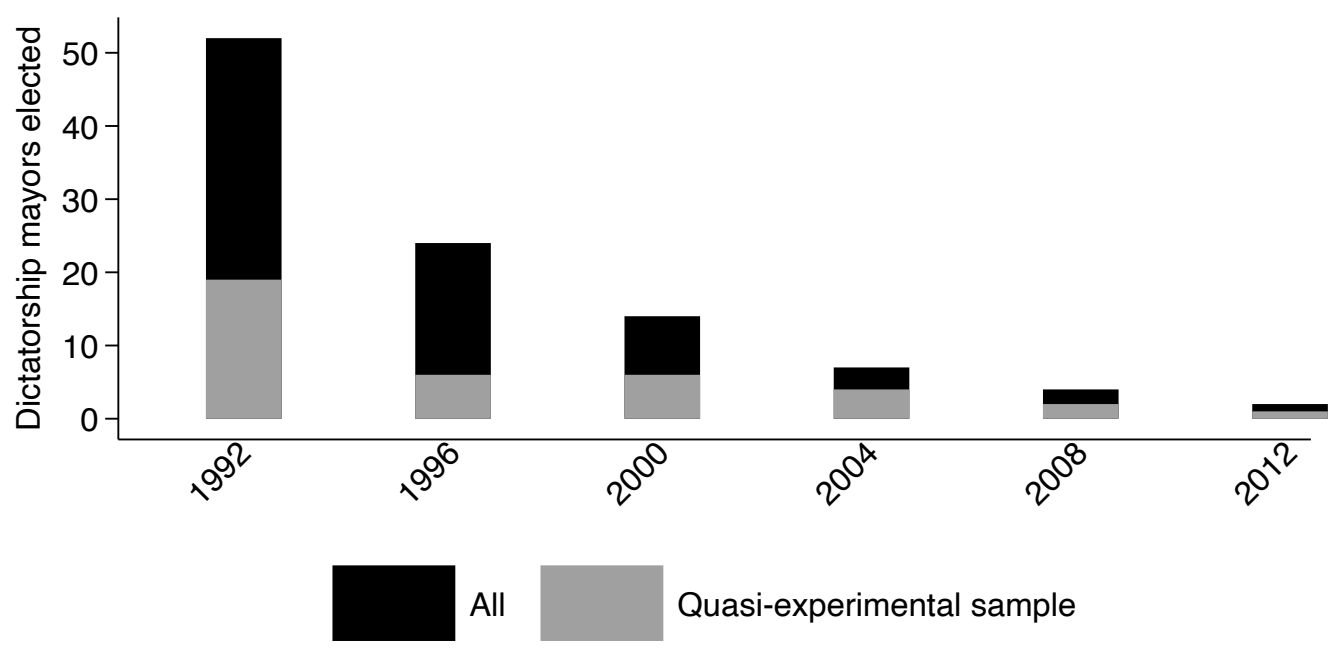

(b) The persistence of dictatorship mayors

Notes: Panel (a) shows the percentage of new mayors around the Pinochet dictatorship (19731990). Before and after the dictatorship period, all mayors in the country were elected in the same electoral process every four years. All mayors were removed from their positions by the time of the 1973 coup and the electoral cycle was reinstalled in June 1992. This figure shows that approximately 10-30\% of mayors were removed from office each year between 1973 and 1990. We constructed the appointments of mayors during the dictatorship period using data from the Ministry of Interior. Each time a mayor was appointed by Pinochet a decree was created with the full name of the mayor, the first date of the mandate, and the name of the municipality. In the few cases without information, we contacted municipalities directly to fill the gaps. Panel (b) shows the total number of dictatorship mayors who were elected in each local election after the return to democracy. "All" corresponds to descriptive statistics using data from all 333 municipalities and the "Quasi-experimental sample" corresponds to the 105 municipalities we focus in section 5. 
Figure 3: The appointments of dictatorship mayors

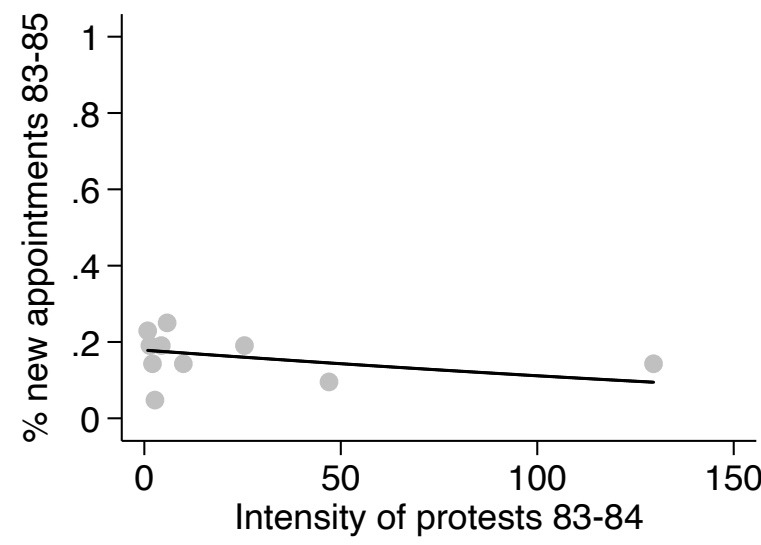

(a) Intensity of protests

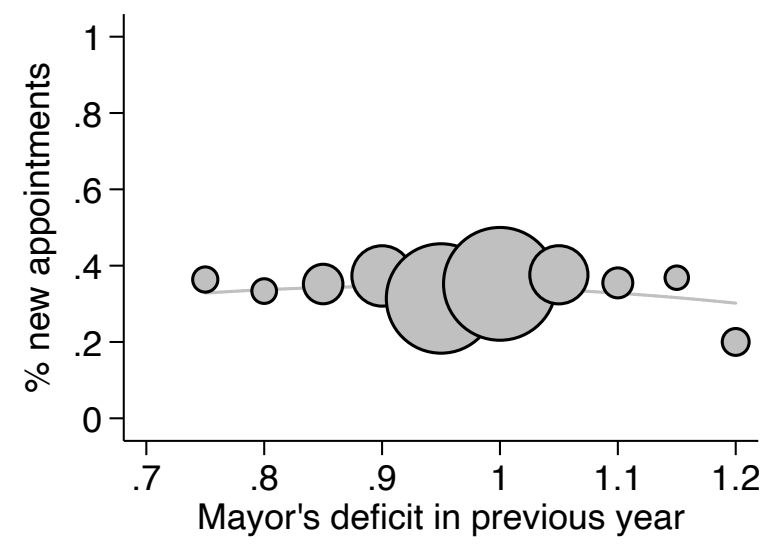

(c) Municipal budget

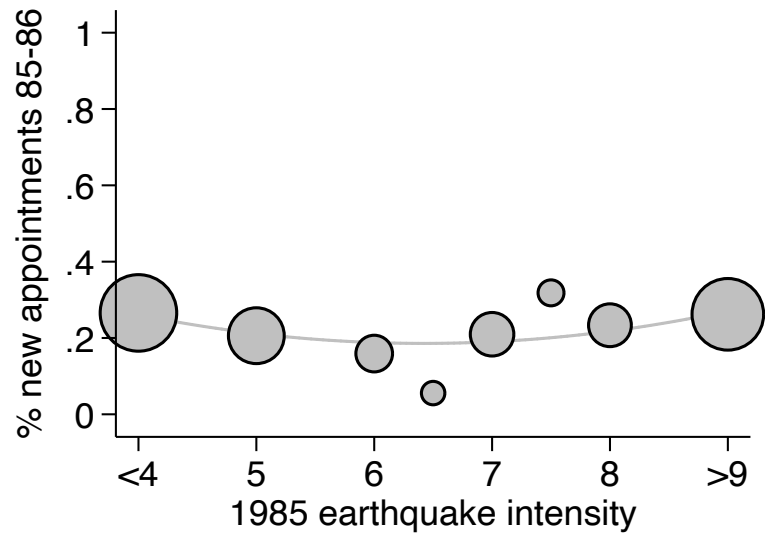

(b) Earthquake intensity

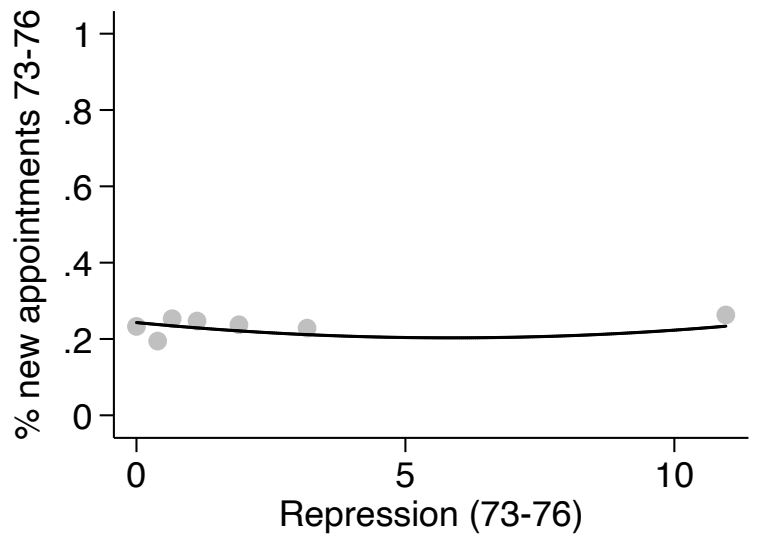

(d) Local repression

Notes: These figures show that mayors were not removed after events that were likely to reveal their performance. We use a panel dataset of municipalities observed every year between 1973 and 1990. The main dependent variable is an indicator that takes the value of one for municipalities where the mayor was replaced. The $y$-axis in all of these figures measure the percentage of new mayors across municipalities in a certain period of time after the performance-related event. Panel (a) shows that the percentage of new appointments in the period 1983-1985 was similar across municipalities with different intensity of protests in the 1983-84 period (bin-scatter plot with 10 quantiles). Panel (b) shows that appointments were again similar across municipalities differentially affected by the 1985 earthquake (bubble size indicates the number of municipalities in the earthquake-intensity bin). Panel (c) shows similar number of new appointments across municipalities with varying degrees of management of municipal budgets (bubble size indicates number of municipalities in the deficit bin). Finally, Panel (d) shows that new appointments in the period 1973-1976 was similar in municipalities with different intensity of state repression as measured by the number of victims per 1,000 inhabitants in the period 1973-1976. 
Figure 4: Local projects implemented by the Ministry of Housing and Urbanization

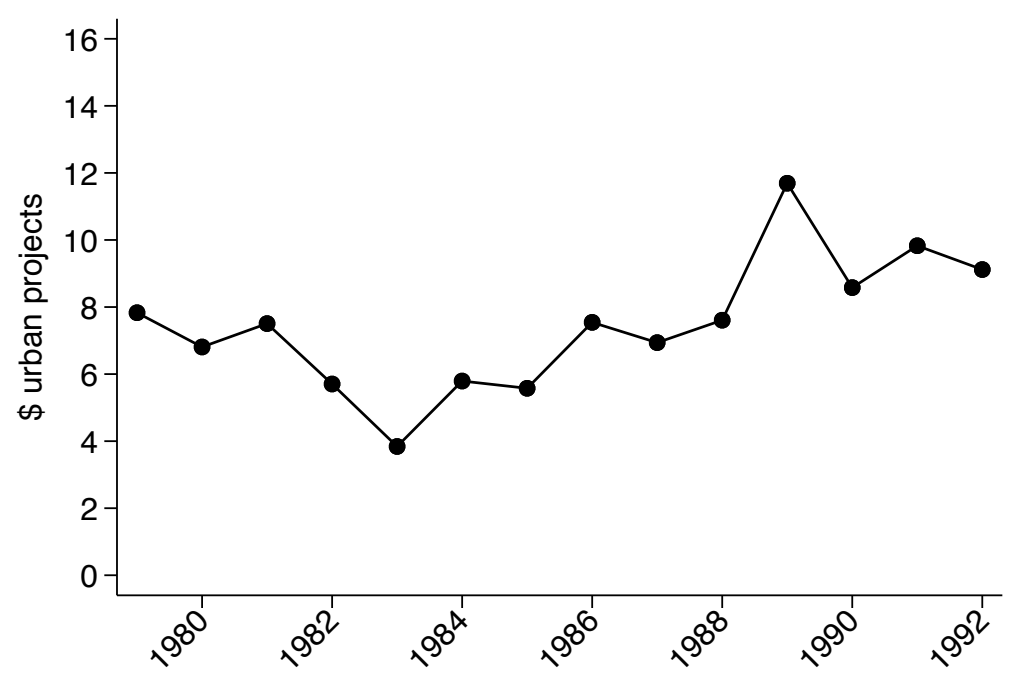

(a) Total cost of local projects $(\$)$

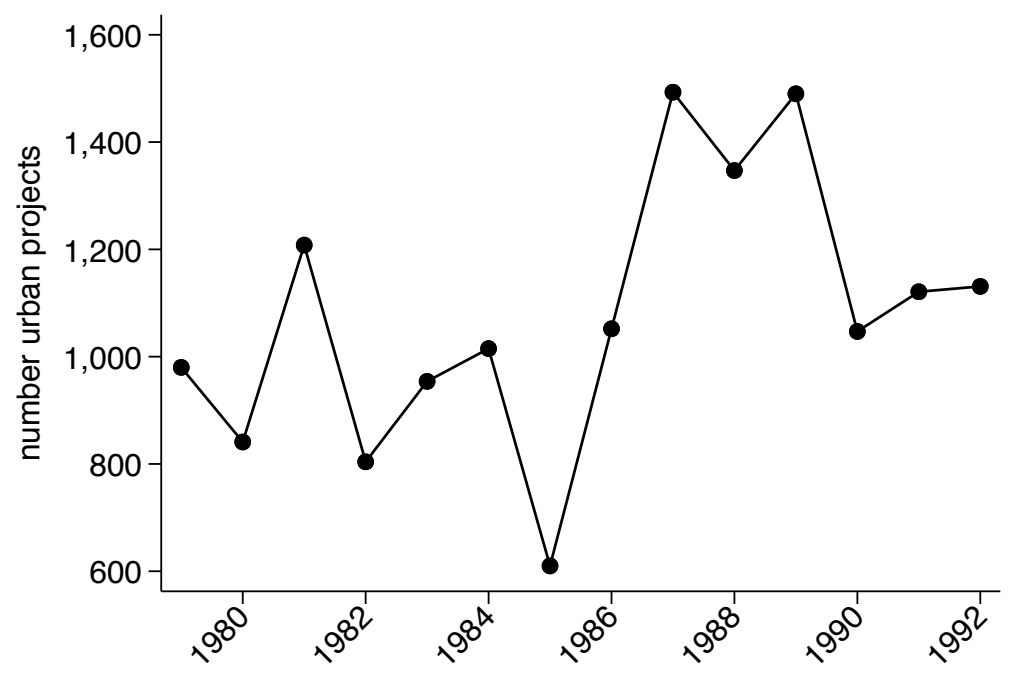

(b) Total number of projects in the reports

Notes: Time series variation in projects implemented by the Ministry of Housing and Urbanization. The data is available from 1979 onwards. We digitized this information from annual reports produced by the Ministry. Examples of these local projects include health infrastructure, paving, lighting, sewerage, fire stations, sport courts, and social housing, among others. Panel (a) presents the total cost of all projects in a given year in monetary units. Panel (b) presents the total number of projects. We use both measures for the analysis in the paper. 
Table 1: Descriptive statistics

\begin{tabular}{|c|c|c|c|c|}
\hline Panel A - Mayors appointed by Pinochet $(\mathrm{N}=1,104)$ & $\frac{\text { Mean }}{(1)}$ & $\frac{\text { St. Dev. }}{(2)}$ & $\frac{\text { Min }}{(3)}$ & $\frac{\text { Max }}{(4)}$ \\
\hline Years of tenure (1973-1987) & 4.14 & 3.60 & 1.00 & 15.00 \\
\hline Municipalities per mayor (1973-1987) & 1.04 & 0.21 & 1.00 & 3.00 \\
\hline Panel B - Municipalities (N=333) & & & & \\
\hline Number of mayors (1973-1987) & 3.22 & 1.61 & 1.00 & 8.00 \\
\hline Local spending (\$) in projects per capita (1979-1987) & 50.16 & 358.22 & 0.00 & 6305.66 \\
\hline Local spending $(\mathrm{N})$ in projects per capita $(1979-1987)$ & 16.85 & 23.55 & 0.00 & 327.87 \\
\hline Municipal revenues per capita (1985-1987) & 15.05 & 35.58 & 0.24 & 605.12 \\
\hline Municipal spending per capita (1985-1987) & 14.94 & 34.98 & 0.35 & 594.41 \\
\hline Budget deficit (1985-1987) & 1.09 & 0.89 & 0.38 & 10.72 \\
\hline
\end{tabular}

Notes: Panel (a) presents descriptive statistics for the 1,104 dictatorship mayors in our data. Panel (b) presents descriptive statistics for the 333 municipalities with data on dictatorship mayors. All variables are measured until the year before the democratization announcement (1988 referendum). "Local spending (\$)" measures the total financial cost of local projects and "Local spending (N)" measures the number of local projects implemented by the Ministry of Housing and Urbanization. Examples of these local projects include health infrastructure, paving, lighting, sewerage, fire stations, sport courts, and social housing, among others. Municipal spending (revenues) corresponds to the total amount of resources spent (collected) by the mayor. Finally, "Budget deficit" is simply defined as the ratio of municipal spending to municipal revenues. All per capita variables use population from the 1970 census. 
Table 2: The decision to run in the 1992 local elections

\begin{tabular}{|c|c|c|c|c|c|c|}
\hline \multicolumn{7}{|c|}{ Dependent variable: Indicator for dictatorship mayors running in the 1992 election } \\
\hline & (1) & (2) & (3) & (4) & $(5)$ & (6) \\
\hline \multirow[t]{2}{*}{ Tenure in $1976-82$} & -0.01 & -0.01 & -0.02 & -0.00 & 0.00 & -0.00 \\
\hline & $(0.03)$ & $(0.03)$ & $(0.03)$ & $(0.04)$ & $(0.04)$ & $(0.04)$ \\
\hline \multirow[t]{2}{*}{ Tenure in $1983-88$} & $0.14 * * *$ & $0.14 * * *$ & $0.14 * * *$ & 0.02 & 0.02 & 0.02 \\
\hline & $(0.03)$ & $(0.03)$ & $(0.03)$ & $(0.04)$ & $(0.04)$ & $(0.04)$ \\
\hline \multirow[t]{2}{*}{ Years of tenure } & $0.01 * * *$ & $0.01 * * *$ & $0.01 * * *$ & 0.01 & 0.01 & 0.01 \\
\hline & $(0.00)$ & $(0.00)$ & $(0.00)$ & $(0.00)$ & $(0.00)$ & $(0.00)$ \\
\hline \multirow[t]{2}{*}{$\times$ Tenure in $1983-88$} & & & & $0.03 * * *$ & $0.03 * * *$ & $0.03 * * *$ \\
\hline & & & & $(0.01)$ & $(0.01)$ & $(0.01)$ \\
\hline \multirow[t]{2}{*}{$\times$ Tenure in $1976-82$} & & & & -0.00 & -0.00 & -0.00 \\
\hline & & & & $(0.01)$ & $(0.01)$ & $(0.01)$ \\
\hline \multirow[t]{2}{*}{ Municipal spending in dictatorship } & & $0.04 *$ & $0.03 *$ & & 0.03 & 0.03 \\
\hline & & $(0.02)$ & $(0.02)$ & & $(0.02)$ & $(0.02)$ \\
\hline \multirow[t]{2}{*}{ Local spending (\$) in dictatorship } & & $-0.06^{*}$ & -0.05 & & $-0.06^{*}$ & $-0.06^{*}$ \\
\hline & & $(0.03)$ & $(0.03)$ & & $(0.03)$ & $(0.03)$ \\
\hline \multirow[t]{2}{*}{ Local spending (projects) in dictatorship } & & 0.01 & 0.01 & & 0.01 & 0.01 \\
\hline & & $(0.01)$ & $(0.01)$ & & $(0.01)$ & $(0.01)$ \\
\hline \multirow[t]{2}{*}{ Municipal spending in transition } & & -0.02 & -0.02 & & -0.02 & -0.02 \\
\hline & & $(0.02)$ & $(0.02)$ & & $(0.02)$ & $(0.02)$ \\
\hline \multirow[t]{2}{*}{ Local spending (\$) in transition } & & 0.01 & 0.02 & & 0.01 & 0.01 \\
\hline & & $(0.02)$ & $(0.02)$ & & $(0.02)$ & $(0.02)$ \\
\hline \multirow[t]{2}{*}{ Local spending (projects) in transition } & & -0.03 & $-0.04 *$ & & $-0.03^{*}$ & $-0.04 * *$ \\
\hline & & $(0.02)$ & $(0.02)$ & & $(0.02)$ & $(0.02)$ \\
\hline \multirow[t]{2}{*}{ Vote share NO in 1988 (referendum) } & & & -0.02 & & & -0.03 \\
\hline & & & $(0.04)$ & & & $(0.04)$ \\
\hline \multirow[t]{2}{*}{ Vote share opposition in 1989 (Aylwin) } & & & 0.02 & & & 0.03 \\
\hline & & & $(0.03)$ & & & $(0.03)$ \\
\hline \multirow[t]{2}{*}{ Victims of repression per 1,000 inhab. } & & & 0.00 & & & 0.00 \\
\hline & & & $(0.01)$ & & & $(0.01)$ \\
\hline \multirow[t]{2}{*}{ Indicator military base in 1970} & & & -0.02 & & & -0.01 \\
\hline & & & $(0.04)$ & & & $(0.04)$ \\
\hline \multirow[t]{2}{*}{ Intensity of protests $1983-84$} & & & -0.01 & & & -0.01 \\
\hline & & & $(0.01)$ & & & $(0.01)$ \\
\hline \multirow[t]{2}{*}{ Indicator female } & $0.08 *$ & $0.07 *$ & $0.07 *$ & 0.07 & 0.06 & 0.06 \\
\hline & $(0.04)$ & $(0.04)$ & $(0.04)$ & $(0.04)$ & $(0.04)$ & $(0.04)$ \\
\hline Observations (dictatorship mayors) & 1,100 & 1,100 & 1,100 & 1,100 & 1,100 & 1,100 \\
\hline R-squared & 0.078 & 0.086 & 0.088 & 0.091 & 0.099 & 0.101 \\
\hline Province fixed effects & Yes & Yes & Yes & Yes & Yes & Yes \\
\hline Avg. dependent variable & 0.17 & 0.17 & 0.17 & 0.17 & 0.17 & 0.17 \\
\hline
\end{tabular}

Notes: Each observation is a dictatorship mayor. Each column is a different cross-sectional regression to understand the determinants of the decision to run in the 1992 local election. "Tenure in 1976-82" and "Tenure in 1983-88" are indicators that take the value of one if the dictatorship mayor held office in the corresponding period. "Years of tenure" corresponds to the number of years in office during the dictatorship. All spending variables are measured per capita using 1970 population data. Victims of repression and the indicator for military bases was originally constructed by Bautista et al. (2020). We construct the "Intensity of protests" using data from reports of documents of the Vicariate of Solidarity. We manually identify female mayors by inspection of their given names. Standard errors are robust to heteroskedasticity. Significance level: $* * *$ $p<0.01, * * p<0.05, * p<0.1$. 
Table 3: Dictatorship mayors in the first democratic local election The dependent variable is the vote share of candidates in the 1992 local election

\begin{tabular}{lcccc}
\hline \hline & $(1)$ & $(2)$ & $(3)$ & $(4)$ \\
& & & & \\
Dictatorship mayor & $9.02 * * *$ & $8.92 * * *$ & $9.36 * * *$ & $6.50 * * *$ \\
& $(0.76)$ & $(0.78)$ & $(0.77)$ & $(0.92)$ \\
& & & & \\
Incumbent mayor & & & & $6.04 * * *$ \\
& & & & $(1.52)$ \\
Candidates (observations) & 6,497 & 6,497 & 6,497 & 6,497 \\
Municipalities & 333 & 333 & 333 & 333 \\
Municipality fixed effects & & $\mathrm{X}$ & $\mathrm{X}$ & $\mathrm{X}$ \\
Political party fixed effects & & & $\mathrm{X}$ & $\mathrm{X}$ \\
R-squared & 0.08 & 0.12 & 0.28 & 0.28 \\
Avg. dependent variable & 5.13 & 5.13 & 5.13 & 5.13 \\
\hline \hline
\end{tabular}

Notes: Each observation is a candidate in the 1992 local election. The number of dictatorship mayors is 246, and the number of incumbent dictatorship mayors is 117 (sitting incumbents). The average number of candidates in a municipality was 20 . The dependent variable is measured in percentages, i.e. from 0 to 100 . Standard errors clustered by municipality in parenthesis. Significance level: *** $p<0.01, * * p<0.05, * p<0.1$. 
Table 4: Incumbency advantage in the 1996 local elections

The dependent variable is the vote share of a candidate in the 1996 local elections

\begin{tabular}{|c|c|c|c|c|c|c|}
\hline & \multicolumn{6}{|c|}{ Municipality races included in the estimation: } \\
\hline & \multicolumn{4}{|c|}{ All } & \multicolumn{2}{|c|}{$\begin{array}{l}\text { Only incumbents } \\
\text { and runner-ups from } \\
\text { previous election }\end{array}$} \\
\hline & $(1)$ & (2) & (3) & (4) & $(5)$ & $(6)$ \\
\hline Incumbent & $\begin{array}{c}23.27 * * * \\
(0.78)\end{array}$ & $\begin{array}{c}23.29 * * * \\
(0.80)\end{array}$ & $\begin{array}{c}22.20 * * * \\
(0.82)\end{array}$ & $\begin{array}{c}22.18 * * * \\
(0.86)\end{array}$ & $\begin{array}{c}12.97 * * * \\
(1.34)\end{array}$ & $\begin{array}{c}13.41 * * * \\
(1.49)\end{array}$ \\
\hline Incumbent $\times$ Dictatorship mayor & & & & $\begin{array}{c}-8.26 * * * \\
(2.74)\end{array}$ & & $\begin{array}{l}-3.10 \\
(5.49)\end{array}$ \\
\hline Dictatorship mayor & & & & $\begin{array}{c}9.90 * * * \\
(1.13)\end{array}$ & & $\begin{array}{c}1.54 \\
(3.78)\end{array}$ \\
\hline Candidates (observations) & 5,466 & 5,466 & 5,466 & 5,466 & 474 & 474 \\
\hline Municipalities & 341 & 341 & 341 & 341 & 214 & 214 \\
\hline Municipality fixed effects & & $X$ & $X$ & $\mathrm{X}$ & $X$ & $\mathrm{X}$ \\
\hline Political party fixed effects & & & $X$ & $X$ & $\mathrm{X}$ & $X$ \\
\hline R-squared & 0.38 & 0.41 & 0.44 & 0.46 & 0.43 & 0.43 \\
\hline Avg. dependent variable & 6.24 & 6.24 & 6.24 & 6.24 & 22.69 & 22.69 \\
\hline
\end{tabular}

Notes: Each observation is a candidate in the 1996 local elections. There were 355 incumbent mayors running for reelection, 38 of which were dictatorship mayors. In addition, 123 dictatorship mayors were non-incumbent candidates. Columns 1-4 include all candidates. Columns 5-6 only include winners (incumbents) and runner-ups from the 1992 elections who decided to run in the 1996 local elections, which occurred in 214 municipalities. In this sub-sample there are 260 incumbent mayors running for reelection, 27 of which were dictatorship mayors. In addition, there were 40 dictatorship mayors who were the runner-ups in 1992. Standard errors clustered by municipality in parenthesis. Significance level: $* * * p<0.01, * * p<0.05, * p<0.1$. 
Table 5: Local elections and local spending in projects

The dependent variable is the vote share of candidates in the 1992 local election

\begin{tabular}{|c|c|c|c|}
\hline \multirow[t]{3}{*}{ Spending variable: } & \multicolumn{2}{|c|}{ Local spending } & \multirow{2}{*}{$\begin{array}{c}\begin{array}{c}\text { Municipal } \\
\text { spending }\end{array} \\
\begin{array}{c}\text { Log spending } \\
\text { per capita }\end{array}\end{array}$} \\
\hline & $\begin{array}{l}\text { Log spending } \\
\text { per capita }\end{array}$ & $\begin{array}{c}\text { Number of } \\
\text { projects per capita }\end{array}$ & \\
\hline & (1) & (2) & (3) \\
\hline Dictatorship mayor & $\begin{array}{c}9.49 * * * \\
(0.77)\end{array}$ & $\begin{array}{c}9.50^{* * * *} \\
(0.77)\end{array}$ & $\begin{array}{c}9.40 * * * \\
(0.74)\end{array}$ \\
\hline$\times$ Spending in democracy & $\begin{array}{c}0.17 \\
(1.13)\end{array}$ & $\begin{array}{l}-0.31 \\
(1.11)\end{array}$ & $\begin{array}{l}2.75 \\
(3.09)\end{array}$ \\
\hline$\times$ Spending in transition & $\begin{array}{l}2.40^{*} \\
(1.29)\end{array}$ & $\begin{array}{l}3.62 * * \\
(1.51)\end{array}$ & $\begin{array}{l}-0.47 \\
(3.41)\end{array}$ \\
\hline$\times$ Spending in dictatorship & $\begin{array}{l}-0.03 \\
(0.94)\end{array}$ & $\begin{array}{c}1.02 \\
(0.91)\end{array}$ & $\begin{array}{c}1.18 \\
(1.94)\end{array}$ \\
\hline Candidates (observations) & 6,274 & 6,274 & 6,274 \\
\hline Municipalities & 324 & 324 & 324 \\
\hline Municipality fixed effects & $\mathrm{X}$ & $\mathrm{X}$ & $\mathrm{X}$ \\
\hline Political party fixed effects & $\mathrm{X}$ & $\mathrm{X}$ & $\mathrm{X}$ \\
\hline Avg. dependent variable & 5.16 & 5.16 & 5.16 \\
\hline
\end{tabular}

Notes: Each observation is a candidate in the 1992 local elections. This table presents estimates

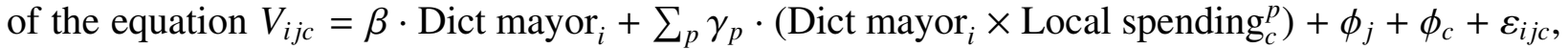
where Local spending ${ }_{c}^{p}$ is local spending in projects (columns 1-2) or municipal spending (column 3 ) in municipality $c$ during period $p$. We call "dictatorship" to the period before October 1988, "transition" to the period between October 1988 and March 1990, and "democracy" to the period between March 1990 and June 1992. The number of dictatorship mayors in the estimating sample is 246. Robust standard errors clustered at the municipality level in parenthesis. Significance level: $* * * p<0.01, * * p<0.05, * p<0.1$. See section 4 for details. 
Table 6: Hypothetical voting scenarios

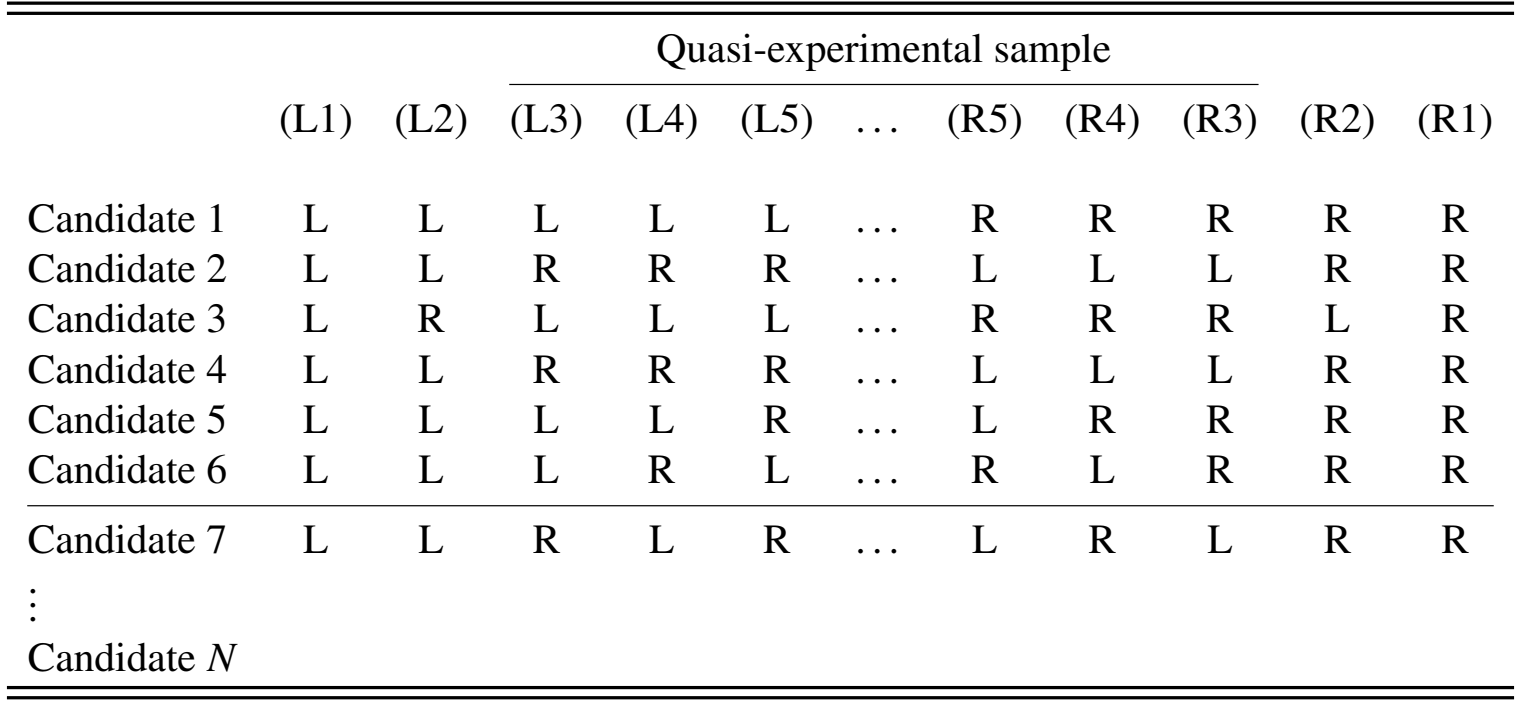

Notes: Hypothetical order of left- (L) and right-wing (R) candidates in a municipality after the 1992 local election. The six most voted candidates were the more likely to become councilors and they had to elect the mayor whenever the most voted candidate obtained less than $35 \%$ of voters or was not part of the most voted list. A list is a group of political parties. "Quasi-experimental sample" corresponds to the subset of municipalities where the order of the 6th/7th candidates had a disproportionate impact on the majority in the council. 
Table 7: Summary statistics and differences by council majority

\begin{tabular}{|c|c|c|c|c|c|}
\hline \multirow[b]{3}{*}{ Panel A - First-stage } & \multicolumn{3}{|c|}{ Summary Statistics } & \multicolumn{2}{|c|}{$\begin{array}{c}\text { Difference in left-wing } \\
\text { majority councils }\end{array}$} \\
\hline & All & $\begin{array}{l}\text { Quasi-exp. } \\
\text { sample }\end{array}$ & $\begin{array}{c}\text { No left-wing } \\
\text { majority }\end{array}$ & Raw diff. & $\begin{array}{l}\text { Including } \\
\text { size controls }\end{array}$ \\
\hline & (1) & (2) & (3) & (4) & (5) \\
\hline Dictatorship mayor elected & 0.12 & 0.16 & 0.24 & $\begin{array}{c}-0.24 * * * \\
(0.05)\end{array}$ & $\begin{array}{c}-0.25 * * * \\
(0.05)\end{array}$ \\
\hline \multicolumn{6}{|l|}{ Panel B - Electoral outcomes } \\
\hline Vote share Allende in 1970 & 35.14 & 33.20 & 32.63 & $\begin{array}{c}1.84 \\
(2.76)\end{array}$ & $\begin{array}{c}1.25 \\
(2.83)\end{array}$ \\
\hline Vote share Alessandri in 1970 & 34.57 & 35.59 & 35.74 & $\begin{array}{l}-0.47 \\
(1.66)\end{array}$ & $\begin{array}{l}-0.40 \\
(1.63)\end{array}$ \\
\hline Vote share left-wing (UP) in 1971 & 48.46 & 46.59 & 45.44 & $\begin{array}{c}3.75 \\
(2.59)\end{array}$ & $\begin{array}{c}3.51 \\
(2.66)\end{array}$ \\
\hline Vote registration in 1988 & 71.99 & 73.36 & 72.99 & $\begin{array}{c}1.16 \\
(6.01)\end{array}$ & $\begin{array}{c}1.40 \\
(6.12)\end{array}$ \\
\hline Vote share NO in 1988 & 34.90 & 34.11 & 35.28 & $\begin{array}{c}1.72 \\
(3.71)\end{array}$ & $\begin{array}{l}1.28 \\
(3.81)\end{array}$ \\
\hline Vote share opposition (Aylwin) in 1989 & 51.96 & 50.84 & 49.78 & $\begin{array}{l}3.44^{*} \\
(1.79)\end{array}$ & $\begin{array}{c}2.85 \\
(1.81)\end{array}$ \\
\hline Share right-wing candidates in 1992 & 51.28 & 51.59 & 52.17 & $\begin{array}{l}-1.86 \\
(1.47)\end{array}$ & $\begin{array}{l}-1.85 \\
(1.57)\end{array}$ \\
\hline Share independent candidates in 1992 & 2.44 & 2.39 & 2.51 & $\begin{array}{l}-0.39 \\
(0.78)\end{array}$ & $\begin{array}{l}-0.41 \\
(0.80)\end{array}$ \\
\hline Share female candidate in 1992 & 11.42 & 11.58 & 12.37 & $\begin{array}{l}-2.61 \\
(2.68)\end{array}$ & $\begin{array}{l}-3.32 \\
(3.22)\end{array}$ \\
\hline Total number of candidates in 1992 & 19.8 & 17.8 & 17.2 & $\begin{array}{c}2.0 * * \\
(0.8)\end{array}$ & $\begin{array}{l}1.2 * \\
(0.7)\end{array}$ \\
\hline \multicolumn{6}{|l|}{ Panel C - Other } \\
\hline Log projects per capita in dictatorship & 0.01 & -0.06 & -0.12 & $\begin{array}{c}0.17 \\
(0.13)\end{array}$ & $\begin{array}{c}0.19 \\
(0.14)\end{array}$ \\
\hline Log projects per capita in transition & 0.01 & -0.06 & -0.12 & $\begin{array}{c}0.19 \\
(0.12)\end{array}$ & $\begin{array}{c}0.17 \\
(0.13)\end{array}$ \\
\hline Log municipal spending per capita in dictatorship & -0.08 & -0.01 & 0.02 & $\begin{array}{l}-0.10 \\
(0.17)\end{array}$ & $\begin{array}{l}-0.07 \\
(0.18)\end{array}$ \\
\hline Log municipal spending per capita in transition & -0.07 & 0.02 & 0.09 & $\begin{array}{l}-0.23 \\
(0.17)\end{array}$ & $\begin{array}{l}-0.21 \\
(0.16)\end{array}$ \\
\hline Log distance to regional capital & 3.84 & 4.04 & 4.13 & $\begin{array}{l}-0.29 \\
(0.21)\end{array}$ & $\begin{array}{l}-0.16 \\
(0.21)\end{array}$ \\
\hline Log distance to Santiago & 5.44 & 5.60 & 5.64 & $\begin{array}{l}-0.16 \\
(0.32)\end{array}$ & $\begin{array}{c}0.15 \\
(0.26)\end{array}$ \\
\hline Houses per capita in 1970 & 0.22 & 0.22 & 0.22 & $\begin{array}{c}0.01 \\
(0.03)\end{array}$ & $\begin{array}{c}0.01 \\
(0.03)\end{array}$ \\
\hline Percentage of women in 1970 & 0.49 & 0.48 & 0.48 & $\begin{array}{c}0.00 \\
(0.01)\end{array}$ & $\begin{array}{c}0.00 \\
(0.01)\end{array}$ \\
\hline Intensity of $1983-84$ protests & 17.21 & 3.00 & 2.90 & $\begin{array}{c}0.27 \\
(1.15)\end{array}$ & $\begin{array}{c}0.06 \\
(0.86)\end{array}$ \\
\hline Victims of state repression per 1,000 inhab. & 2.23 & 2.75 & 1.57 & $\begin{array}{c}3.66 \\
(4.42) \\
\end{array}$ & $\begin{array}{c}3.96 \\
(4.76) \\
\end{array}$ \\
\hline Municipalities & 284 & 104 & 104 & 104 & 104 \\
\hline
\end{tabular}

Notes: Averages in columns 1-3. Column 4 show the coefficient from a regression of each variable on the left-wing majority indicator (the excluded instrument). Column 5 shows the same difference than in column 4 but controlling for the size of the council. Robust standard errors in parenthesis in columns 4-5. Significance level: *** $\mathrm{p}<0.01,{ }^{* *} \mathrm{p}<0.05,{ }^{*} \mathrm{p}<0.1$ 
Table 8: The political legacies of dictatorship mayors

\begin{tabular}{|c|c|c|c|c|c|c|c|c|}
\hline \multirow{4}{*}{ Dependent variable: } & \multicolumn{2}{|c|}{ All municipalities } & \multicolumn{6}{|c|}{ Quasi-experimental sample } \\
\hline & \multirow{3}{*}{$\begin{array}{c}\text { Local } \\
\text { elections }\end{array}$} & \multirow{3}{*}{$\begin{array}{c}\begin{array}{c}\text { Presidential } \\
\text { elections }\end{array} \\
\text { Vote sha } \\
\text { (2) }\end{array}$} & \multicolumn{2}{|c|}{$\begin{array}{l}\text { Local } \\
\text { elections }\end{array}$} & \multicolumn{2}{|c|}{$\begin{array}{c}\text { Presidential } \\
\text { elections }\end{array}$} & \multicolumn{2}{|c|}{ Local elections 1996-2000 } \\
\hline & & & of right $-w$ & ng candida & & & $\begin{array}{l}\text { Right-wing } \\
\text { mayor elected }\end{array}$ & $\begin{array}{l}\% \text { right-wing } \\
\text { councilors }\end{array}$ \\
\hline & & & (3) & (4) & (5) & (6) & (7) & $(8)$ \\
\hline \multicolumn{9}{|l|}{ Panel A - Second-stage } \\
\hline Dictatorship mayor elected & $\begin{array}{l}39.02 * * * \\
(10.66)\end{array}$ & $\begin{array}{l}29.24 * * * \\
(7.81)\end{array}$ & $\begin{array}{l}18.77 * \\
(9.91)\end{array}$ & & $\begin{array}{l}9.56 * \\
(5.46)\end{array}$ & & $\begin{array}{c}0.23 \\
(0.23)\end{array}$ & $\begin{array}{l}0.18 * * \\
(0.08)\end{array}$ \\
\hline Right-wing mayor elected & & & & $\begin{array}{l}9.74 * * \\
(4.54)\end{array}$ & & $\begin{array}{l}3.55 \\
(2.64)\end{array}$ & & \\
\hline \multicolumn{9}{|l|}{ Panel B - First-stage } \\
\hline Left-wing council majority & $\begin{array}{c}-0.20 * * * \\
(0.04)\end{array}$ & $\begin{array}{c}-0.20 * * * \\
(0.04)\end{array}$ & $\begin{array}{c}-0.26 * * * \\
(0.06)\end{array}$ & $\begin{array}{c}-0.56 * * * \\
(0.07)\end{array}$ & $\begin{array}{c}-0.26^{* * * *} \\
(0.06)\end{array}$ & $\begin{array}{c}-0.56 * * * \\
(0.07)\end{array}$ & $\begin{array}{c}-0.26 * * * \\
(0.06)\end{array}$ & $\begin{array}{c}-0.26 * * * \\
(0.06)\end{array}$ \\
\hline Observations & 1,669 & 1,704 & 613 & 513 & 624 & 522 & 208 & 208 \\
\hline Municipalities & 283 & 283 & 104 & 87 & 104 & 87 & 104 & 104 \\
\hline Avg. dependent variable (panel A) & 36.84 & 40.91 & 38.59 & 38.57 & 41.84 & 41.38 & 0.45 & 0.20 \\
\hline Year fixed effects & $\mathrm{X}$ & $\mathrm{X}$ & $\mathrm{X}$ & $\mathrm{X}$ & $\mathrm{X}$ & $\mathrm{X}$ & $\mathrm{X}$ & $\mathrm{X}$ \\
\hline $\mathrm{K}$-P $F$-statistic & 24.42 & 24.99 & 21.22 & 63.77 & 21.42 & 64.66 & 21.2 & 21.3 \\
\hline
\end{tabular}

Notes: Panel A presents two-stage least square estimates of equation (3) and panel B the corresponding first-stage (equation 4). The electoral period of local elections goes from 1996 to 2016 (6 elections) and of presidential elections goes from 1993 to 2017 (6 elections). The treatment variables "Dictatorship mayor elected" and "Right-wing mayor elected" are measured in the 1992 local election. In columns 1-6 we examine all elections after 1992 and columns 7-8 restrict attention to local elections in 1996 and 2000 due to changes in electoral rules from the 2004 election onwards. All specifications control by municipality size category, margin of victory, and include year fixed effects. Standard errors clustered at the municipality level in parenthesis. Significance level: $* * * p<0.01, * * p<0.05, * p<0.1$. 
Table 9: The performance of dictatorship mayors

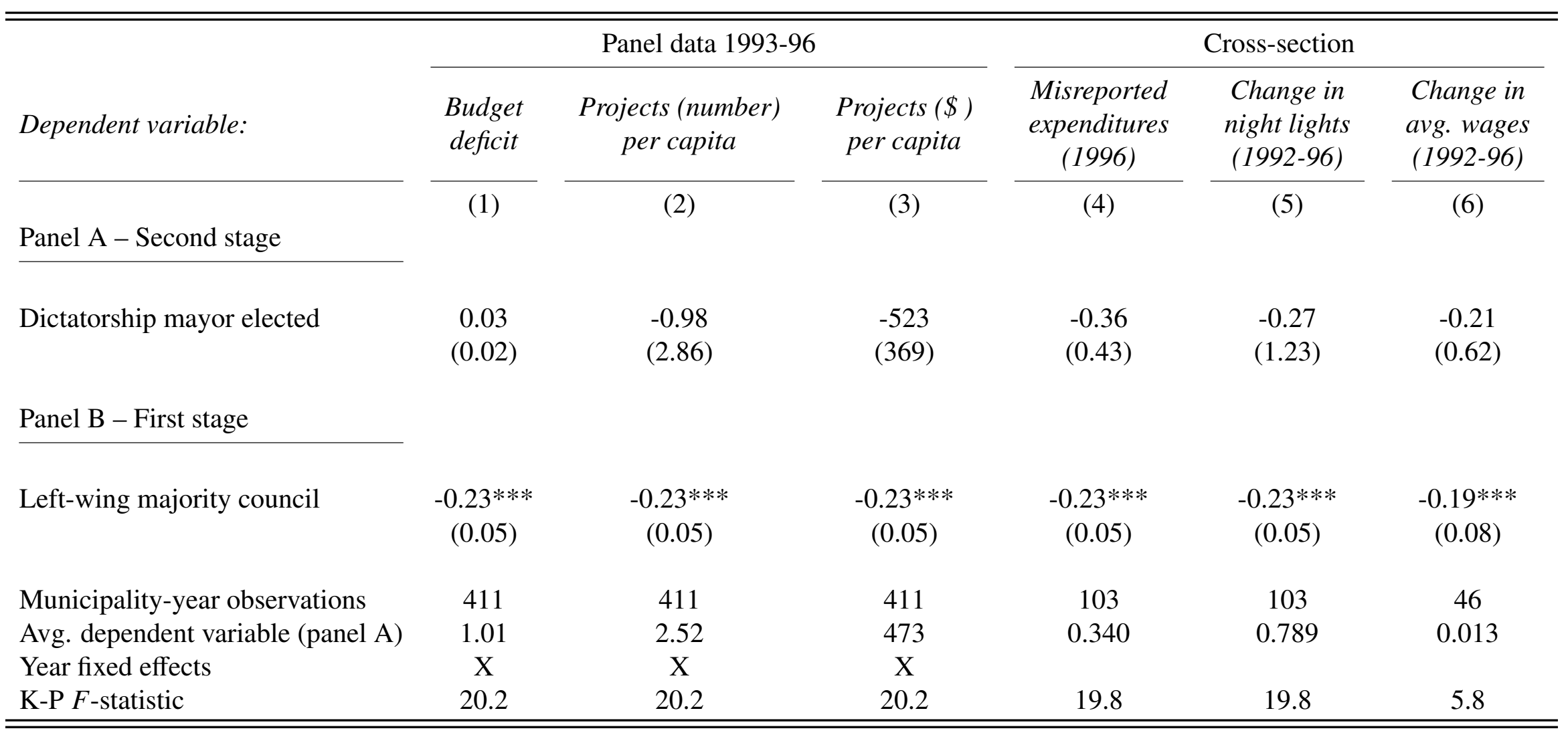

Notes: Panel A presents two-stage least square estimates of equation (3) and panel B the corresponding first-stage (equation 4) in columns 1-3. Columns 4-6 repeat the estimation but using a cross-sectional data of municipalities. All specifications control by municipality size category and victory margin. "Budget deficit" is defined as municipal spending over municipal revenues. The projects in columns 2-3 are measured in logarithm per capita. "Misreported expenditures" corresponds to an indicator that takes the value of one for municipalities which misreported expenditures to the Comptroller Office. Night lights data come from Henderson et al. (2012). Changes in average wages comes from the CASEN surveys. Robust standard errors in parenthesis. Significance level: $* * * \mathrm{p}<0.01, * * \mathrm{p}<0.05, * \mathrm{p}<0.1$. 


\section{Online Appendix}

Lost in transition? The persistence of dictatorship mayors

\section{List of Figures}

A.1 Who profited from the electoral rule in the 1992 election $\ldots \ldots \ldots$ ii

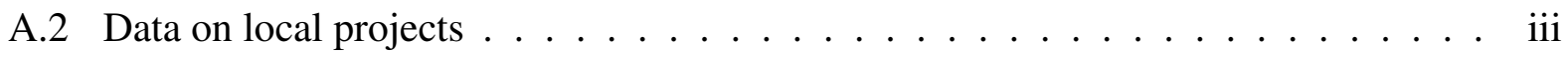

A.3 Data on municipal spending $\ldots \ldots \ldots \ldots \ldots$ iv

A.4 Share of incumbent dictatorship mayors who ran in $1992 \ldots \ldots \ldots$. . . . . . v

\section{List of Tables}

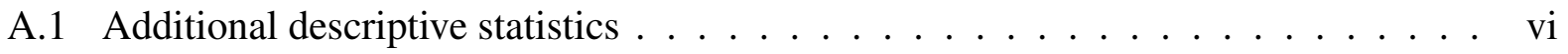

A.2 Local spending in dictatorship and the transition to democracy . . . . . . . vii

A.3 Winners in the first local election . . . . . . . . . . . . . . . viii

A.4 Robustness to flexible fixed effects by party in $1992 \ldots \ldots \ldots$. . . . . . . ix

A.5 Robustness to flexible fixed effects by party in $1996 \ldots \ldots \ldots$. . . . . . . .

A.6 Repression and the vote premium of dictatorship mayors $\ldots \ldots \ldots$. . . . . xi

A.7 The vote premium among incumbent and non-incumbent dictatorship mayors _ . . xii

A.8 Candidates presidential elections 1993 - $2017 \ldots \ldots$. . . . . . . . . . . xiii

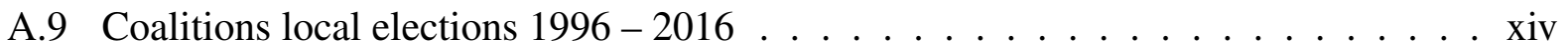

A.10 Dictatorship mayors and electoral competition in democracy $\ldots \ldots \ldots$ xv

A.11 Political legacies in local elections by year $\ldots \ldots \ldots \ldots$. . . . . . . . . .

A.12 Political legacies in presidential elections by year $\ldots \ldots \ldots \ldots$. . . . . . . .

A.13 Robustness to smaller vote margins $\ldots \ldots \ldots \ldots \ldots \ldots$ xviii

A.14 Robustness to additional controls . . . . . . . . . . . . . . xix

A.16 Dictatorship mayors and category of projects $1993-1996 \ldots \ldots$. . . . . . xxi 
Figure A.1: Who profited from the electoral rule in the 1992 election

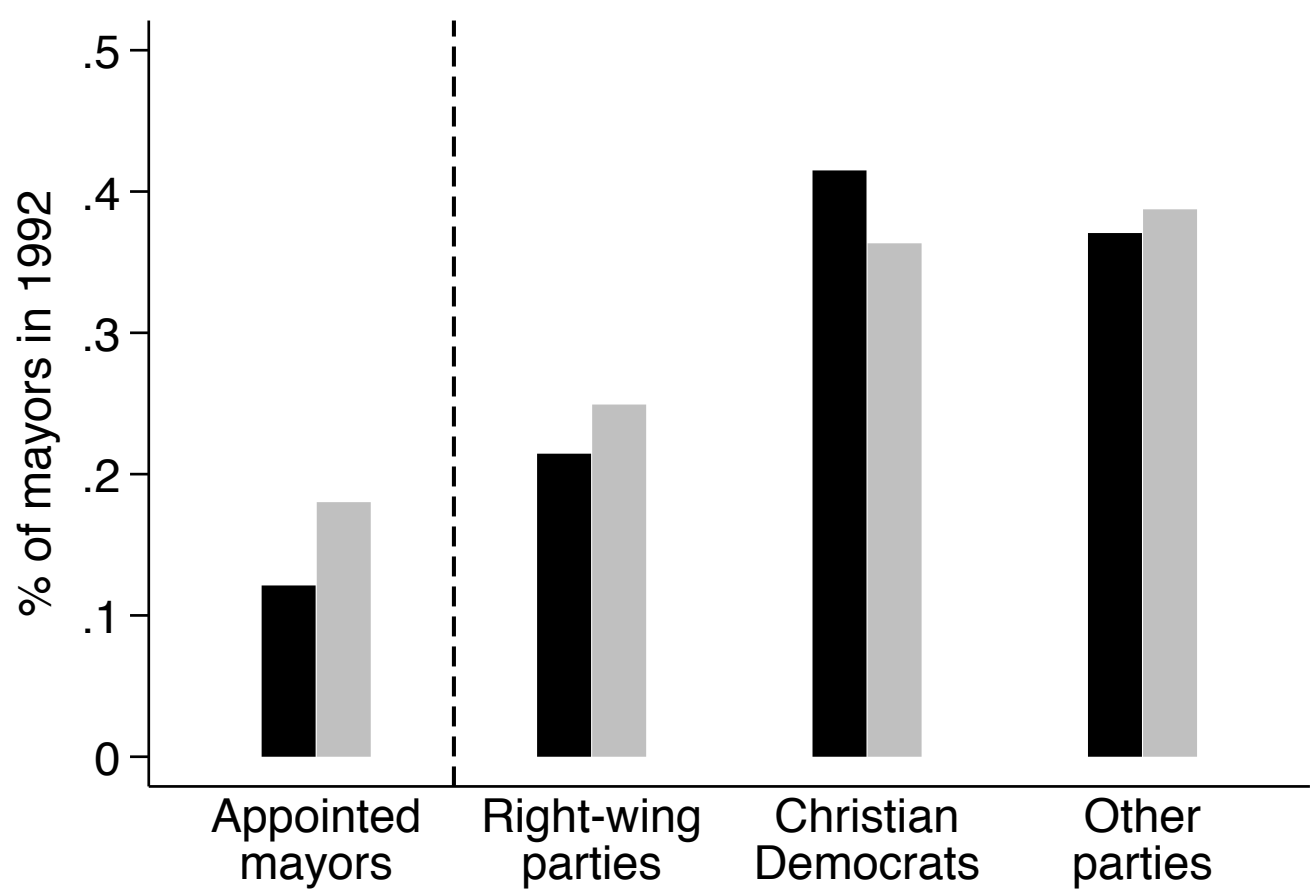

Notes: Electoral results (black bars) and counterfactual results (gray bars) in the 1992 local elections under different electoral rules. Percentage of mayors by appointed or not in the left part of the figure and by political party in the right part of the figure. Black bars indicate the actual percentage of mayors elected, while gray bars represent the percentage of mayors elected in a counterfactual world with a simple majority rule to elect mayors. Section 2 provides more details. 
Figure A.2: Data on local projects

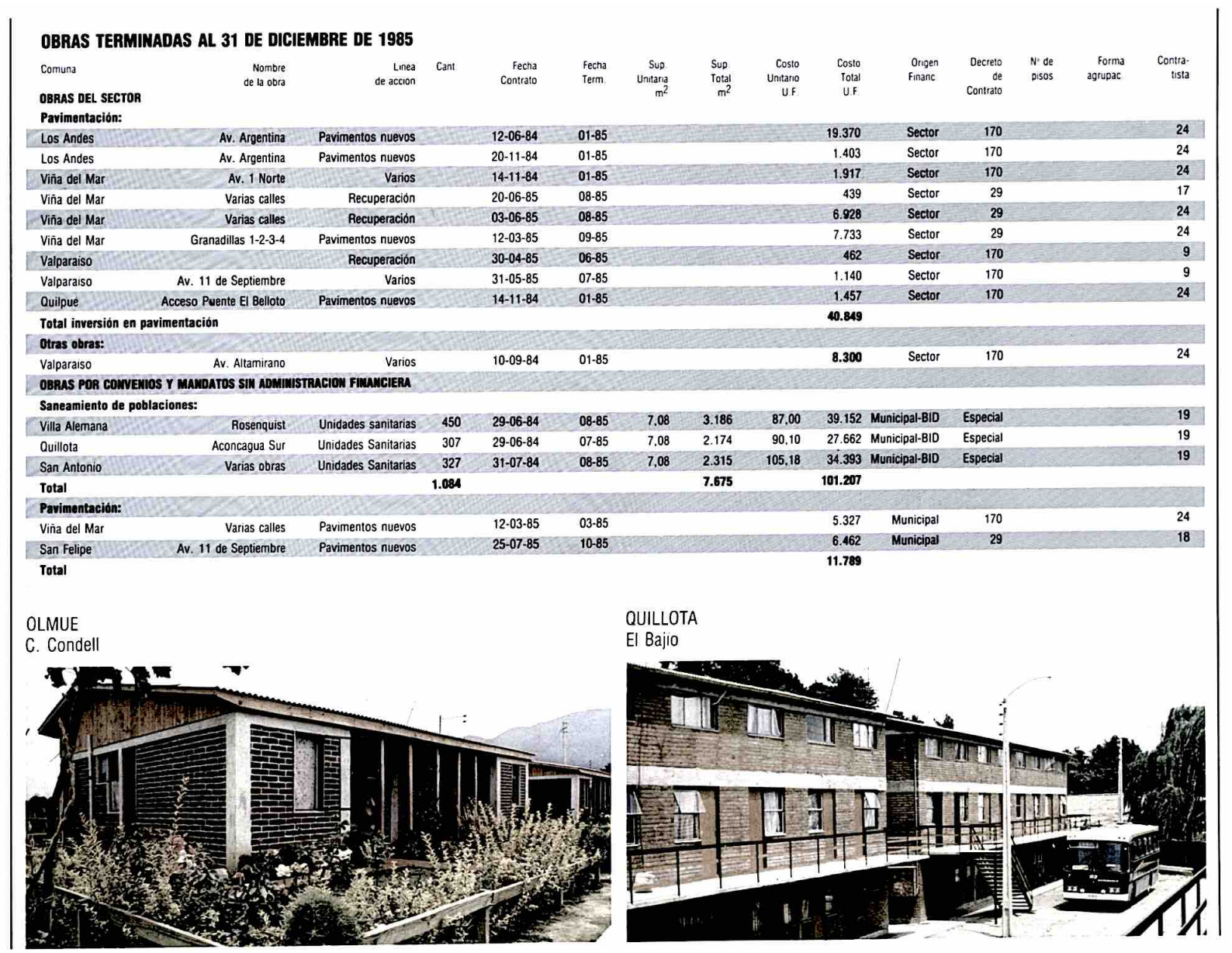

Notes: Section 3 provides more details. 
Figure A.3: Data on municipal spending

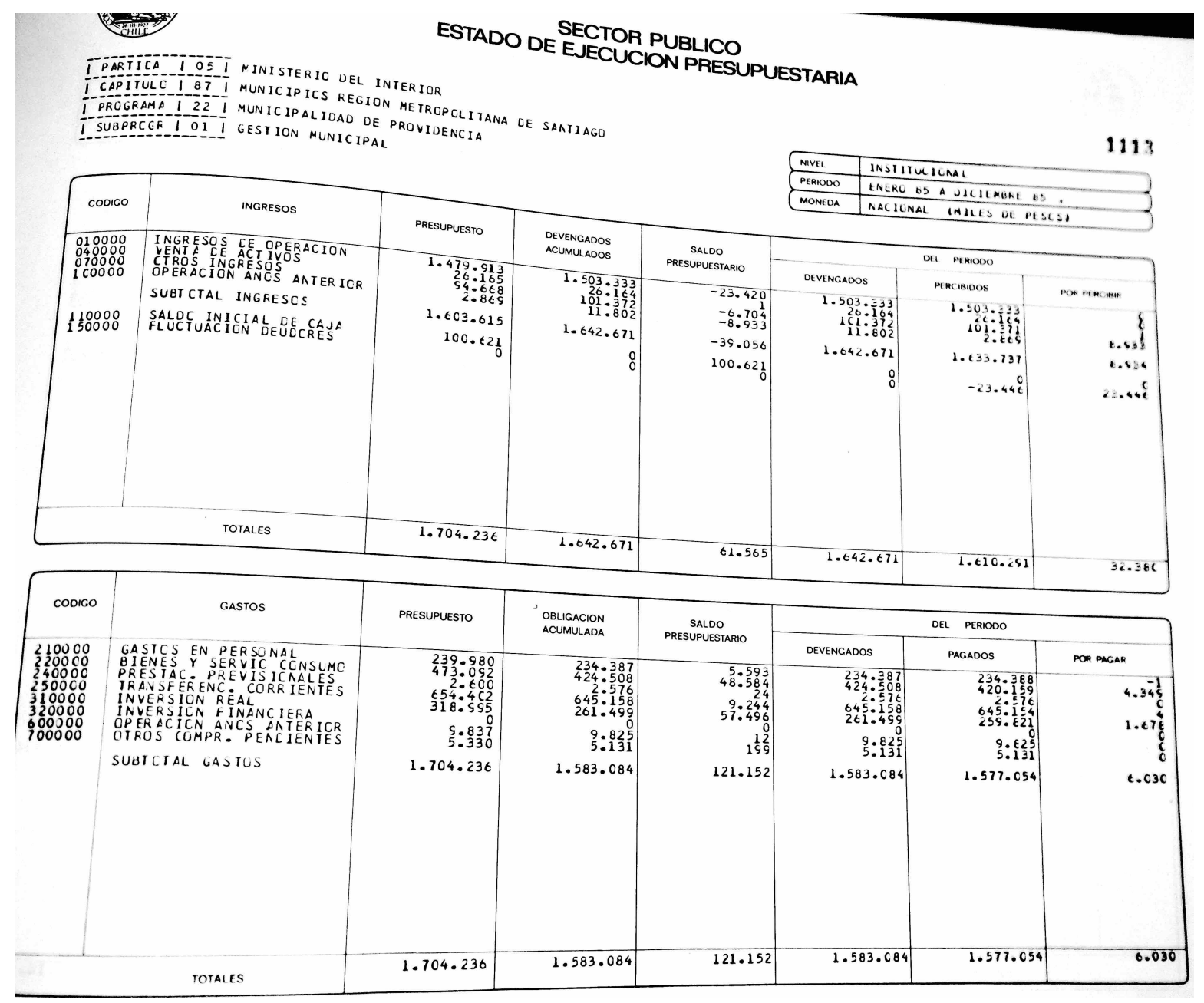

Notes: Section 3 provides more details. 
Figure A.4: Share of incumbent dictatorship mayors who ran in 1992

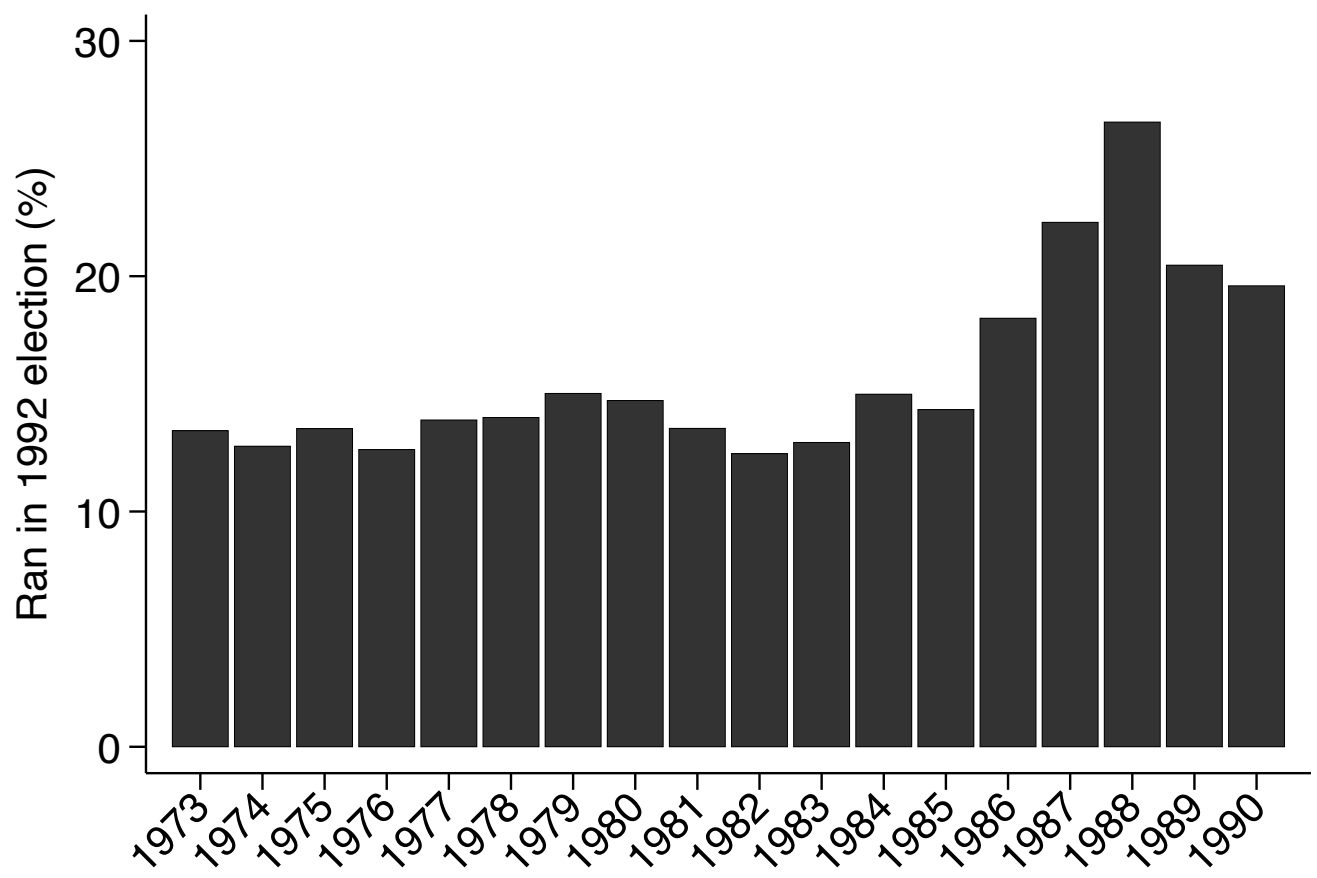

Notes: This figure shows the percentage of dictatorship mayors who decided to run in the 1992 election in each year that Pinochet was in power (1973-1990). In each year we observe all dictatorship mayors and then we check how many of them ran as candidate for mayor in 1992. The figure clearly shows that dictatorship mayors who were in office towards the end of the dictatorship were more likely to run in the 1992 election. 
Table A.1: Additional descriptive statistics

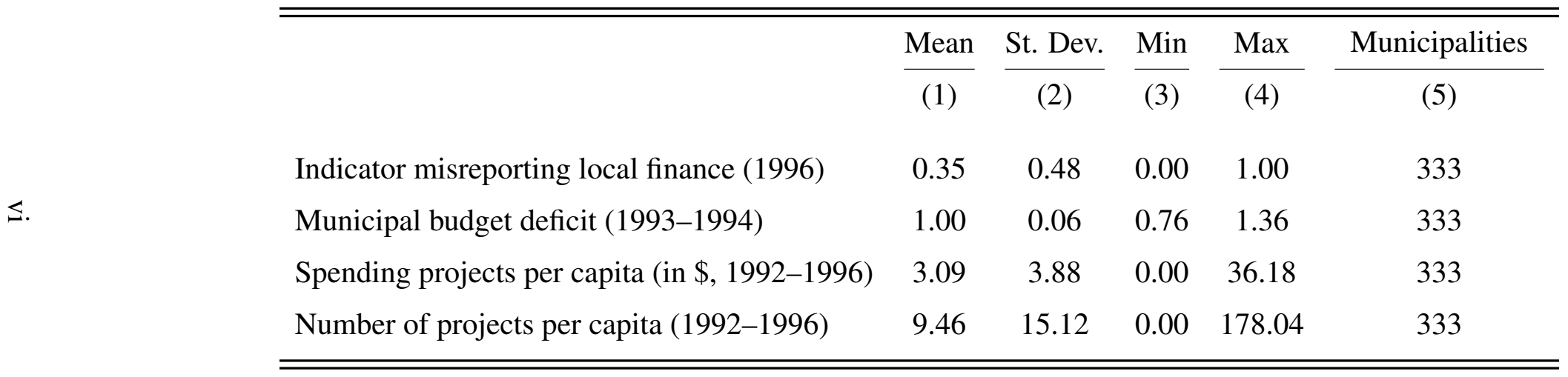

Notes: Data for misreporting of local finance and budget deficit comes from the General Accounting Office. Data for projects comes from annual reports of the Ministry of Housing and Urbanization. 
Table A.2: Local spending in dictatorship and the transition to democracy

\begin{tabular}{|c|c|c|c|c|c|c|}
\hline \multirow{4}{*}{ Local spending variable: } & \multicolumn{3}{|c|}{ in dictatorship } & \multicolumn{3}{|c|}{ during transition } \\
\hline & \multicolumn{2}{|c|}{ Projects } & \multirow{2}{*}{$\frac{\text { Municipal }}{\log \$}$} & \multicolumn{2}{|c|}{ Projects } & \multirow{2}{*}{$\begin{array}{c}\text { Municipal } \\
\log \$\end{array}$} \\
\hline & $\log \$$ & Number & & $\log \$$ & Number & \\
\hline & (1) & $(2)$ & (3) & (4) & $(5)$ & $(6)$ \\
\hline Vote share for the right wing candidate in 1970 & $\begin{array}{l}-0.08 \\
(0.18)\end{array}$ & $\begin{array}{l}-10.20 \\
(12.11)\end{array}$ & $\begin{array}{l}0.26^{* *} \\
(0.13)\end{array}$ & $\begin{array}{c}0.44 \\
(0.35)\end{array}$ & $\begin{array}{l}-1.65 \\
(1.66)\end{array}$ & $\begin{array}{l}-0.03 \\
(0.07)\end{array}$ \\
\hline Vote share for the left-wing candidate in 1970 & $\begin{array}{l}-0.07 \\
(0.20)\end{array}$ & $\begin{array}{l}-16.29 \\
(12.81)\end{array}$ & $\begin{array}{c}0.13 \\
(0.13)\end{array}$ & $\begin{array}{c}0.02 \\
(0.40)\end{array}$ & $\begin{array}{c}1.45 \\
(2.09)\end{array}$ & $\begin{array}{l}-0.03 \\
(0.06)\end{array}$ \\
\hline Victims of repression per 1,000 inhab. & $\begin{array}{c}0.01 \\
(0.04)\end{array}$ & $\begin{array}{c}-0.16 \\
(1.94)\end{array}$ & $\begin{array}{c}0.04 \\
(0.04)\end{array}$ & $\begin{array}{c}0.15 \\
(0.10)\end{array}$ & $\begin{array}{l}-0.01 \\
(0.22)\end{array}$ & $\begin{array}{c}0.02 \\
(0.01)\end{array}$ \\
\hline Indicator military base in 1970 & $\begin{array}{c}0.89 * * * \\
(0.28)\end{array}$ & $\begin{array}{c}-14.88 * * \\
(6.77)\end{array}$ & $\begin{array}{c}-0.48 * * * \\
(0.16)\end{array}$ & $\begin{array}{c}1.15^{* * * *} \\
(0.44)\end{array}$ & $\begin{array}{l}-1.25 \\
(1.22)\end{array}$ & $\begin{array}{c}-0.23 * * \\
(0.10)\end{array}$ \\
\hline Intensity of protests $1983-84$ & $\begin{array}{l}-0.10 \\
(0.08)\end{array}$ & $\begin{array}{l}-0.78 \\
(0.75)\end{array}$ & $\begin{array}{c}0.07 \\
(0.05)\end{array}$ & $\begin{array}{l}-0.18 \\
(0.13)\end{array}$ & $\begin{array}{l}-0.09 \\
(0.21)\end{array}$ & $\begin{array}{c}0.08 * * * \\
(0.03)\end{array}$ \\
\hline Vote share NO in 1988 (referendum) & & & & $\begin{array}{c}1.65^{* * * *} \\
(0.54)\end{array}$ & $\begin{array}{l}-1.33 \\
(1.73)\end{array}$ & $\begin{array}{c}-0.27 * * * \\
(0.08)\end{array}$ \\
\hline Vote share opposition in 1989 (Aylwin) & & & & $\begin{array}{l}-0.90 * \\
(0.54)\end{array}$ & $\begin{array}{l}-4.20 \\
(4.48)\end{array}$ & $\begin{array}{c}0.04 \\
(0.08)\end{array}$ \\
\hline Municipalities & 321 & 321 & 320 & 321 & 321 & 315 \\
\hline R-squared & 0.185 & 0.142 & 0.322 & 0.355 & 0.323 & 0.431 \\
\hline Province fixed effects & Yes & Yes & Yes & Yes & Yes & Yes \\
\hline Avg. dependent variable & 10.78 & 27.63 & 3.69 & 7.37 & 4.25 & 3.98 \\
\hline
\end{tabular}

Notes: Standard errors are robust to heteroscedasticity. Significance level: *** $p<0.01, * * p<0.05, * p<0.1$. 
Table A.3: Winners in the first local election

The dependent variable is an indicator for the winners of the 1992 local election

\begin{tabular}{lcccc}
\hline \hline & $(1)$ & $(2)$ & $(3)$ & $(4)$ \\
& & & & \\
Dictatorship mayor & $0.15^{* * *}$ & $0.15^{* * * *}$ & $0.18^{* * *}$ & $0.13^{* * *}$ \\
& $(0.03)$ & $(0.03)$ & $(0.03)$ & $(0.03)$ \\
& & & & \\
Incumbent mayor & & & & $0.10^{* *}$ \\
& & & & $(0.05)$ \\
Candidates & 6,497 & 6,497 & 6,497 & 6,497 \\
Municipalities & 333 & 333 & 333 & 333 \\
R-squared & 0.02 & 0.03 & 0.10 & 0.11 \\
Municipality fixed effects & & $\mathrm{X}$ & $\mathrm{X}$ & $\mathrm{X}$ \\
Political party fixed effects & & & $\mathrm{X}$ & $\mathrm{X}$ \\
Mean of dependent variable & 0.07 & 0.07 & 0.07 & 0.07 \\
\hline \hline
\end{tabular}

Notes: Each observation is a candidate in the 1992 local election. The number of dictatorship mayors is 246. Standard errors clustered by municipality in parenthesis. Significance level: *** $p<0.01, * * p<0.05, * p<0.1$. 
Table A.4: Robustness to flexible fixed effects by party in 1992

\begin{tabular}{|c|c|c|c|c|}
\hline & \multicolumn{2}{|c|}{ Vote share } & \multicolumn{2}{|c|}{ Indicator elected } \\
\hline & (1) & (2) & (3) & (4) \\
\hline Dictatorship mayor & $\begin{array}{c}9.35^{* * * *} \\
(0.77)\end{array}$ & $\begin{array}{c}9.48 * * * \\
(0.76)\end{array}$ & $\begin{array}{c}0.18 * * * \\
(0.03)\end{array}$ & $\begin{array}{c}0.18 * * * \\
(0.03)\end{array}$ \\
\hline Candidates & 6,491 & 6,481 & 6,491 & 6,481 \\
\hline Municipalities & 333 & 333 & 333 & 333 \\
\hline R-squared & 0.30 & 0.31 & 0.12 & 0.14 \\
\hline Municipality fixed effects & $\mathrm{X}$ & $\mathrm{X}$ & $\mathrm{X}$ & $\mathrm{X}$ \\
\hline Political party by region fixed effects & $X$ & & $\mathrm{X}$ & \\
\hline Political party by province fixed effects & & $\mathrm{X}$ & & $\mathrm{X}$ \\
\hline Avg. dependent variable & 5.13 & 5.13 & 0.07 & 0.07 \\
\hline
\end{tabular}

Notes: Each observation is a candidate in the 1992 local election. The number of dictatorship mayors is 246 and the number of incumbent dictatorship mayors is 117. Standard errors clustered by municipality in parenthesis. Significance level: ${ }^{* * *} p<0.01,{ }^{* *} p<0.05, * p<0.1$. 
Table A.5: Robustness to flexible fixed effects by party in 1996

The dependent variable is the vote share of candidates in the 1996 local election

\begin{tabular}{|c|c|c|c|c|c|c|c|c|}
\hline \multirow[t]{2}{*}{ Sample: } & Full & Restricted & Full & Restricted & Full & Restricted & Full & Restricted \\
\hline & (1) & (2) & (3) & (4) & (5) & (6) & (7) & (8) \\
\hline Incumbent & $\begin{array}{c}21.96 * * * \\
(0.81)\end{array}$ & $\begin{array}{c}13.36 * * * \\
(1.63)\end{array}$ & $\begin{array}{c}21.96 * * * \\
(0.85)\end{array}$ & $\begin{array}{c}14.56^{* * * *} \\
(1.88)\end{array}$ & $\begin{array}{c}21.97 * * * \\
(0.81)\end{array}$ & $\begin{array}{c}13.74 * * * \\
(1.85)\end{array}$ & $\begin{array}{c}21.97 * * * \\
(0.85)\end{array}$ & $\begin{array}{c}13.88 * * * \\
(2.19)\end{array}$ \\
\hline Incumbent $\times$ Dictatorship mayor & & & $\begin{array}{c}-8.38 * * * \\
(2.76)\end{array}$ & $\begin{array}{l}-8.25 \\
(6.81)\end{array}$ & & & $\begin{array}{c}-8.83 * * * \\
(2.70)\end{array}$ & $\begin{array}{c}-0.98 \\
(8.11)\end{array}$ \\
\hline Dictatorship mayor & & & $\begin{array}{c}10.05^{* * * *} \\
(1.12)\end{array}$ & $\begin{array}{c}5.56 \\
(4.57)\end{array}$ & & & $\begin{array}{c}10.55^{* * * *} \\
(1.14)\end{array}$ & $\begin{array}{c}1.16 \\
(5.05)\end{array}$ \\
\hline Candidates (observations) & 5,463 & 436 & 5,463 & 436 & 5,435 & 396 & 5,435 & 396 \\
\hline R-squared & 0.459 & 0.528 & 0.482 & 0.533 & 0.471 & 0.629 & 0.496 & 0.630 \\
\hline Municipalities & 341 & 196 & 341 & 196 & 340 & 179 & 340 & 179 \\
\hline Municipality fixed effects & $\mathrm{X}$ & $\mathrm{X}$ & $\mathrm{X}$ & $\mathrm{X}$ & $X$ & $\mathrm{X}$ & $\mathrm{X}$ & $\mathrm{X}$ \\
\hline Political party by region fixed effects & $X$ & $\mathrm{X}$ & $X$ & $X$ & & & & \\
\hline Political party by province fixed effects & & & & & X & $X$ & $\mathrm{X}$ & $\mathrm{X}$ \\
\hline Avg. dependent variable & 6.242 & 22.70 & 6.242 & 22.70 & 6.248 & 22.88 & 6.248 & 22.88 \\
\hline
\end{tabular}

Notes: Each observation is a candidate in the 1996 local election. . The full sample includes all candidates, while the restricted sample only includes winners (incumbents) and runner-ups from the 1992 elections who decided to run in the 1996 local elections, which occurred in 214 municipalities. In this sub-sample there are 260 incumbent mayors running for reelection, 27 of which were dictatorship mayors. In addition, there were 40 dictatorship mayors who were the runner-ups in 1992. Standard errors clustered by municipality in parenthesis. Significance level: $* * * p<0.01, * * p<0.05, * p<0.1$. 
Table A.6: Repression and the vote premium of dictatorship mayors The dependent variable is the vote share of candidates in the 1992 local election

\begin{tabular}{|c|c|c|c|}
\hline \multirow[t]{3}{*}{ Local spending variable: } & \multicolumn{2}{|c|}{ Development projects } & \multirow{2}{*}{$\begin{array}{c}\begin{array}{c}\text { Municipal } \\
\text { spending }\end{array} \\
\text { Log spending } \\
\text { per capita }\end{array}$} \\
\hline & $\begin{array}{l}\text { Log spending } \\
\text { per capita }\end{array}$ & $\begin{array}{c}\text { Number of } \\
\text { projects per capita }\end{array}$ & \\
\hline & (1) & (2) & (3) \\
\hline Dictatorship mayor & $\begin{array}{c}9.57 * * * \\
(0.79)\end{array}$ & $\begin{array}{c}9.64 * * * \\
(0.79)\end{array}$ & $\begin{array}{c}9.50 * * * \\
(0.76)\end{array}$ \\
\hline$\times$ Spending in democracy & $\begin{array}{c}0.19 \\
(1.13)\end{array}$ & $\begin{array}{c}-0.36 \\
(1.15)\end{array}$ & $\begin{array}{l}2.45 \\
(2.88)\end{array}$ \\
\hline$\times$ Spending in transition & $\begin{array}{l}2.36^{*} \\
(1.33)\end{array}$ & $\begin{array}{l}3.74 * * \\
(1.50)\end{array}$ & $\begin{array}{l}-0.22 \\
(3.26)\end{array}$ \\
\hline$\times$ Spending in dictatorship & $\begin{array}{l}-0.05 \\
(0.96)\end{array}$ & $\begin{array}{c}1.10 \\
(0.94)\end{array}$ & $\begin{array}{c}1.26 \\
(1.91)\end{array}$ \\
\hline$\times$ Repression victims per 1,000 inhab & $\begin{array}{l}1.31 \\
(2.26)\end{array}$ & $\begin{array}{l}2.08 \\
(2.20)\end{array}$ & $\begin{array}{l}1.48 \\
(2.13)\end{array}$ \\
\hline Candidates (observations) & 6,274 & 6,274 & 6,274 \\
\hline Municipalities & 324 & 324 & 324 \\
\hline Municipality fixed effects & $\mathrm{X}$ & $\mathrm{X}$ & $\mathrm{X}$ \\
\hline Political party fixed effects & $\mathrm{X}$ & $\mathrm{X}$ & $\mathrm{X}$ \\
\hline Avg. dependent variable & 5.164 & 5.164 & 5.164 \\
\hline
\end{tabular}

Notes: Each observation is a candidate in the 1992 local elections. The number of dictatorship mayors is 246 . Robust standard errors clustered at the municipality level in parenthesis. Significance level: ${ }^{* * *} p<0.01,{ }^{* *} p<0.05, * p<0.1$. See section 4 for details. 
Table A.7: The vote premium among incumbent and non-incumbent dictatorship mayors

The dependent variable is the vote share of candidates in the 1992 local election

\begin{tabular}{|c|c|c|c|}
\hline \multirow[t]{3}{*}{ Local spending variable: } & \multicolumn{2}{|c|}{ Development projects } & \multirow{3}{*}{$\begin{array}{c}\begin{array}{c}\text { Municipal } \\
\text { spending }\end{array} \\
\begin{array}{c}\text { Log spending } \\
\text { per capita }\end{array} \\
(3)\end{array}$} \\
\hline & $\begin{array}{l}\text { Log spending } \\
\text { per capita }\end{array}$ & $\begin{array}{c}\text { Number of } \\
\text { projects per capita }\end{array}$ & \\
\hline & (1) & (2) & \\
\hline Non-Incumbent dictatorship mayor & $\begin{array}{c}6.35 * * * \\
(0.88)\end{array}$ & $\begin{array}{c}6.70 * * * \\
(0.94)\end{array}$ & $\begin{array}{c}6.56 * * * \\
(0.92)\end{array}$ \\
\hline$\times$ Spending in democracy & $\begin{array}{l}-2.60 \\
(2.05)\end{array}$ & $\begin{array}{l}-0.73 \\
(1.27)\end{array}$ & $\begin{array}{c}4.71 \\
(3.51)\end{array}$ \\
\hline$\times$ Spending in transition & $\begin{array}{c}1.87 \\
(1.64)\end{array}$ & $\begin{array}{c}2.02 \\
(2.63)\end{array}$ & $\begin{array}{l}-7.85 \\
(5.07)\end{array}$ \\
\hline$\times$ Spending in dictatorship & $\begin{array}{c}1.90 \\
(1.26)\end{array}$ & $\begin{array}{c}1.50 \\
(0.96)\end{array}$ & $\begin{array}{c}6.91 * * * \\
(2.56)\end{array}$ \\
\hline Incumbent dictatorship mayor & $\begin{array}{c}12.47 * * * \\
(1.19)\end{array}$ & $\begin{array}{c}12.50 * * * \\
(1.20)\end{array}$ & $\begin{array}{c}12.28 * * * \\
(1.12)\end{array}$ \\
\hline$\times$ Spending in democracy & $\begin{array}{c}0.64 \\
(0.74)\end{array}$ & $\begin{array}{c}0.05 \\
(1.60)\end{array}$ & $\begin{array}{l}8.92 * \\
(4.65)\end{array}$ \\
\hline$\times$ Spending in transition & $\begin{array}{l}3.79 \\
(2.63)\end{array}$ & $\begin{array}{l}3.16^{*} \\
(1.70)\end{array}$ & $\begin{array}{l}-1.41 \\
(3.54)\end{array}$ \\
\hline$\times$ Spending in dictatorship & $\begin{array}{l}-3.33 \\
(2.91)\end{array}$ & $\begin{array}{c}1.43 \\
(3.06)\end{array}$ & $\begin{array}{c}-4.59 * * \\
(2.12)\end{array}$ \\
\hline Candidates (observations) & 6,274 & 6,274 & 6,274 \\
\hline Municipalities & 324 & 324 & 324 \\
\hline Municipality fixed effects & $\mathrm{X}$ & $\mathrm{X}$ & $\mathrm{X}$ \\
\hline Political party fixed effects & $\mathrm{X}$ & $\mathrm{X}$ & $\mathrm{X}$ \\
\hline Avg. dependent variable & 5.164 & 5.164 & 5.164 \\
\hline
\end{tabular}

Notes: Each observation is a candidate in the 1992 local elections. The number of dictatorship mayors is 246 and the number of dictatorship prisoners is 514. Robust standard errors clustered at the municipality level in parenthesis. Significance level: *** $p<0.01$, ** $p<0.05, * p<0.1$. See section 4 for details. 
Table A.8: Candidates presidential elections 1993 - 2017

\begin{tabular}{|c|c|c|c|c|c|c|}
\hline Coalition & 1993 & 1999 & 2005 & 2009 & 2013 & 2017 \\
\hline Right-wing & $\begin{array}{l}\text { A. Alessandri } \\
\text { J. Piñera }\end{array}$ & J. Lavín & $\begin{array}{l}\text { S. Piñera } \\
\text { J. Lavín }\end{array}$ & S. Piñera & E. Matthei & $\begin{array}{l}\text { S. Piñera } \\
\text { J.A. Kast }\end{array}$ \\
\hline Left-wing & $\begin{array}{c}\text { E. Frei } \\
\text { M. Max Neef } \\
\text { E. Pizarro } \\
\text { C. Reitze }\end{array}$ & $\begin{array}{l}\text { R. Lagos } \\
\text { G. Marín } \\
\text { T. Hirsch }\end{array}$ & $\begin{array}{c}\text { M. Bachelet } \\
\text { T. Hirsch }\end{array}$ & $\begin{array}{c}\text { E. Frei } \\
\text { J. Arrate } \\
\text { M. Enríquez }\end{array}$ & $\begin{array}{l}\text { M. Bachelet } \\
\text { M. Enríquez } \\
\text { M. Claude } \\
\text { A. Sfeir } \\
\text { R. Miranda }\end{array}$ & $\begin{array}{l}\text { A. Guillier } \\
\text { C. Goic } \\
\text { M. Enríquez } \\
\text { E. Artés } \\
\text { A. Navarro } \\
\text { B. Sánchez }\end{array}$ \\
\hline
\end{tabular}

Notes: Own construction based on administrative data from the Electoral Service. 
Table A.9: Coalitions local elections 1996 - 2016

\begin{tabular}{|c|c|c|c|c|c|c|}
\hline & 1996 & 2000 & 2004 & 2008 & 2012 & 2016 \\
\hline Right-wing & $\begin{array}{l}\text { Participación y Prog. } \\
\text { U. Centro Centro }\end{array}$ & $\begin{array}{c}\text { Alianza } \\
\text { Centro Centro }\end{array}$ & $\begin{array}{c}\text { Alianza } \\
\text { Centro Centro }\end{array}$ & Alianza & Alianza & $\begin{array}{l}\text { Chile Vamos } \\
\text { Amplitud }\end{array}$ \\
\hline Left-wing & $\begin{array}{l}\text { Concertación } \\
\text { P. Comunista }\end{array}$ & $\begin{array}{c}\text { Concertación } \\
\text { La Izquierda } \\
\text { Humanistas y Ecologistas }\end{array}$ & $\begin{array}{l}\text { Concertación } \\
\text { Juntos Podemos } \\
\text { Hum. y Eco. }\end{array}$ & $\begin{array}{l}\text { Concertación Dem. } \\
\text { Juntos Podemos } \\
\text { Hum. y Eco. } \\
\text { Concertación Prog. } \\
\text { Chile Limpio } \\
\text { Fza. Norte }\end{array}$ & $\begin{array}{l}\text { Concertación Dem. } \\
\text { Chile en Otra } \\
\text { El Cambio Por Ti } \\
\text { Más Humanos } \\
\text { Desarrollo Norte } \\
\text { Chile Justo }\end{array}$ & $\begin{array}{c}\text { Nueva Mayoría } \\
\text { Cambiemos la Historia } \\
\text { Yo Marco por el Cambio } \\
\text { Alternativa Democrática } \\
\text { Other (smaller) }\end{array}$ \\
\hline
\end{tabular}

Notes: Own construction based on administrative data from the Electoral Service. 
Table A.10: Dictatorship mayors and electoral competition in democracy

The dependent variable is a measure of ex-ante or ex-post electoral competition

\begin{tabular}{|c|c|c|c|c|c|c|}
\hline \multirow[b]{2}{*}{ Dependent variable: } & \multicolumn{3}{|c|}{ Period: 1996-2000 } & \multicolumn{3}{|c|}{ Period: 2004-2016 } \\
\hline & Victory margin & $\begin{array}{l}\text { Number of } \\
\text { candidates }\end{array}$ & $H H I$ & Victory margin & $\begin{array}{l}\text { Number of } \\
\text { candidates }\end{array}$ & $H H I$ \\
\hline & (1) & (2) & (3) & (4) & (5) & (6) \\
\hline \multicolumn{7}{|l|}{ Panel A - Second stage } \\
\hline Dictatorship Mayor Elected & $\begin{array}{l}-0.03 \\
(0.08)\end{array}$ & $\begin{array}{l}-2.31 \\
(2.39)\end{array}$ & $\begin{array}{c}-0.14 * * \\
(0.06)\end{array}$ & $\begin{array}{c}0.13 \\
(0.09)\end{array}$ & $\begin{array}{l}-1.04 * \\
(0.56)\end{array}$ & $\begin{array}{c}0.07 \\
(0.05)\end{array}$ \\
\hline \multicolumn{7}{|l|}{ Panel B - First stage } \\
\hline Left-wing majority & $\begin{array}{c}-0.26 * * * \\
(0.06)\end{array}$ & $\begin{array}{c}-0.26 * * * \\
(0.06)\end{array}$ & $\begin{array}{c}-0.26 * * * \\
(0.06)\end{array}$ & $\begin{array}{c}-0.26 * * * \\
(0.06)\end{array}$ & $\begin{array}{c}-0.26 * * * \\
(0.06)\end{array}$ & $\begin{array}{c}-0.26 * * * \\
(0.06)\end{array}$ \\
\hline Municipality-year observations & 210 & 210 & 210 & 416 & 419 & 420 \\
\hline Avg. dependent variable & 0.15 & 13.44 & 0.48 & 0.19 & 3.27 & 0.47 \\
\hline KP F-test & 21.18 & 21.18 & 21.18 & 21.31 & 21.36 & 21.33 \\
\hline
\end{tabular}

Notes: "HHI" stands for Herfindhal-Hirschman Index and measures the concentration of vote shares with higher values meaning more concentration and hence less competition. Robust standard errors in parenthesis. Significance level: $* * * \mathrm{p}<0.01, * * \mathrm{p}<0.05, * \mathrm{p}<0.1$. 
Table A.11: Political legacies in local elections by year The dependent variable is the vote share of right-wing candidates

\begin{tabular}{|c|c|c|c|c|c|c|}
\hline & 1996 & 2000 & 2004 & 2008 & 2012 & 2016 \\
\hline Panel A - Second stage & (1) & (2) & (3) & (4) & (5) & (6) \\
\hline Dictatorship mayor elected & $\begin{array}{c}44.98 * * * \\
(14.22)\end{array}$ & $\begin{array}{c}13.64 \\
(13.25)\end{array}$ & $\begin{array}{c}23.30 \\
(14.31)\end{array}$ & $\begin{array}{c}3.45 \\
(13.33)\end{array}$ & $\begin{array}{c}21.10 \\
(15.35)\end{array}$ & $\begin{array}{c}5.65 \\
(15.72)\end{array}$ \\
\hline \multicolumn{7}{|l|}{ Panel B - First stage } \\
\hline Left-wing majority & $\begin{array}{c}-0.23 * * * \\
(0.05)\end{array}$ & $\begin{array}{c}-0.23 * * * \\
(0.05)\end{array}$ & $\begin{array}{c}-0.23 * * * \\
(0.05)\end{array}$ & $\begin{array}{c}-0.24 * * * \\
(0.05)\end{array}$ & $\begin{array}{c}-0.24 * * * \\
(0.05)\end{array}$ & $\begin{array}{c}-0.23 * * * \\
(0.05)\end{array}$ \\
\hline Municipalities & 105 & 105 & 105 & 104 & 100 & 100 \\
\hline Avg. dependent variable & 39.38 & 40.50 & 36.83 & 37.21 & 38.29 & 40.13 \\
\hline KP F-test & 20.86 & 20.86 & 20.86 & 20.95 & 19.42 & 19.13 \\
\hline
\end{tabular}

Notes: All specifications only consider the set of municipalities with a close council composition, restrict attention to elections with at least one right-wing candidate, and control by municipality size category and victory margin. The number of municipalities with at least one right-wing candidate in the quasi-experimental sample drops from 105 to 100 from 2004 2016. Robust standard errors in parenthesis. Significance level: $* * * \mathrm{p}<0.01, * * \mathrm{p}<0.05,{ }^{*} \mathrm{p}<0.1$. 
Table A.12: Political legacies in presidential elections by year

The dependent variable is the vote share of right-wing candidates

\begin{tabular}{|c|c|c|c|c|c|c|}
\hline & 1993 & 1999 & 2005 & 2009 & 2013 & 2017 \\
\hline & (1) & (2) & (3) & (4) & (5) & (6) \\
\hline \multicolumn{7}{|l|}{ Panel A - Second stage } \\
\hline Dictatorship mayor elected & $\begin{array}{c}8.13 \\
(5.24)\end{array}$ & $\begin{array}{l}11.02 \\
(6.95)\end{array}$ & $\begin{array}{c}8.32 \\
(6.08)\end{array}$ & $\begin{array}{c}5.87 \\
(5.83)\end{array}$ & $\begin{array}{l}9.22 * \\
(5.15)\end{array}$ & $\begin{array}{c}14.80 * * \\
(7.15)\end{array}$ \\
\hline \multicolumn{7}{|l|}{ Panel B - First stage } \\
\hline Left-wing majority & $\begin{array}{c}-0.23 * * * \\
(0.05)\end{array}$ & $\begin{array}{c}-0.23 * * * \\
(0.05)\end{array}$ & $\begin{array}{c}-0.23 * * * \\
(0.05)\end{array}$ & $\begin{array}{c}-0.23 * * * \\
(0.05)\end{array}$ & $\begin{array}{c}-0.23 * * * \\
(0.05)\end{array}$ & $\begin{array}{c}-0.23 * * * \\
(0.05)\end{array}$ \\
\hline Municipalities & 105 & 105 & 105 & 105 & 105 & 105 \\
\hline Avg. dependent variable & 32.17 & 51.29 & 50.70 & 45.33 & 23.96 & 47.82 \\
\hline KP F-test & 20.86 & 20.86 & 20.86 & 20.86 & 20.86 & 20.86 \\
\hline
\end{tabular}

Notes: All specifications only consider the set of municipalities with a close council composition, and control by municipality size category and victory margin. Robust standard errors in parenthesis. Significance level: $* * * \mathrm{p}<0.01, * * \mathrm{p}<0.05, * \mathrm{p}<0.1$. 
Table A.13: Robustness to smaller vote margins

\begin{tabular}{|c|c|c|c|c|c|c|}
\hline \multirow{2}{*}{$\begin{array}{l}\text { Sample: } \\
\text { Dependent variable: }\end{array}$} & \multicolumn{3}{|c|}{ Vote margin $<5 \mathrm{pp}$. } & \multicolumn{3}{|c|}{ Vote margin $<2.5 \mathrm{pp}$. } \\
\hline & $\begin{array}{c}\text { Right-wing } \\
\text { vote share in } \\
\text { local elections }\end{array}$ & $\begin{array}{c}\text { Right-wing } \\
\text { vote share in } \\
\text { presid. elections }\end{array}$ & $\begin{array}{l}\% \text { right-wing } \\
\text { councilors } \\
\text { elected }\end{array}$ & $\begin{array}{c}\text { Right-wing } \\
\text { vote share in } \\
\text { local elections }\end{array}$ & $\begin{array}{c}\text { Right-wing } \\
\text { vote share in } \\
\text { presid. elections }\end{array}$ & $\begin{array}{l}\text { \% right-wing } \\
\text { councilors } \\
\text { elected }\end{array}$ \\
\hline & (1) & (2) & (3) & (4) & (5) & (6) \\
\hline Dictatorship mayor & $\begin{array}{l}19.08 * \\
(10.05)\end{array}$ & $\begin{array}{c}8.67 \\
(5.48)\end{array}$ & $\begin{array}{c}0.19 * * \\
(0.09)\end{array}$ & $\begin{array}{l}21.62 * \\
(11.85)\end{array}$ & $\begin{array}{c}8.17 \\
(6.07)\end{array}$ & $\begin{array}{l}0.21^{*} \\
(0.11)\end{array}$ \\
\hline Avg. dependent variable & 38.71 & 41.96 & 0.201 & 38.75 & 41.76 & 0.204 \\
\hline KP F-test & 21.24 & 21.44 & 21.22 & 16.55 & 16.36 & 16.18 \\
\hline
\end{tabular}

Notes: All specifications only consider the set of municipalities with a close council composition, and control by municipality size category, victory margin, and include year fixed effects. Standard errors clustered at the municipality level in parenthesis. Significance level: $* * * \mathrm{p}<0.01, * * \mathrm{p}<0.05, * \mathrm{p}<0.1$. 
Table A.14: Robustness to additional controls

The dependent variable is the vote share of right-wing candidates

\begin{tabular}{|c|c|c|c|c|c|c|}
\hline \multirow[t]{2}{*}{ Dependent variable } & \multicolumn{2}{|c|}{$\begin{array}{c}\text { Right-wing } \\
\text { vote share in } \\
\text { local elections }\end{array}$} & \multicolumn{2}{|c|}{$\begin{array}{l}\text { Right-wing } \\
\text { vote share in } \\
\text { presid. elect. }\end{array}$} & \multicolumn{2}{|c|}{$\begin{array}{l}\text { \% right-wing } \\
\text { councilors } \\
\text { elected }\end{array}$} \\
\hline & (1) & (2) & (3) & (4) & (5) & (6) \\
\hline Dictatorship mayor & $\begin{array}{c}18.90^{*} \\
(9.88)\end{array}$ & $\begin{array}{l}12.79 \\
(9.43)\end{array}$ & $\begin{array}{l}9.16^{*} \\
(5.41)\end{array}$ & $\begin{array}{c}10.05^{* *} \\
(4.68)\end{array}$ & $\begin{array}{c}0.18^{* *} \\
(0.08)\end{array}$ & $\begin{array}{r}0.11 \\
(0.07)\end{array}$ \\
\hline Observations & 619 & 513 & 630 & 522 & 210 & 174 \\
\hline Avg. dependent variable & 38.72 & 38.18 & 41.88 & 41.27 & 0.202 & 0.197 \\
\hline KP F-test & 21.19 & 16.35 & 21.39 & 16.02 & 21.11 & 15.12 \\
\hline+ Vote margin ${ }^{2}$ & Yes & Yes & Yes & Yes & Yes & Yes \\
\hline + Other Controls & No & Yes & No & Yes & No & Yes \\
\hline
\end{tabular}

Notes: All specifications only consider the set of municipalities with a close council composition, and control by municipality size category, victory margin, and include year fixed effects. Other controls include right-wing vote share in 1958, vote share Eduardo Frei in 1964, right- and leftwing vote shares in 1970, an indicator for left-wing mayor in 1971, distances to Santiago and the regional capital, population density, and the percentage of women. Standard errors clustered at the municipality level in parenthesis. Significance level: ${ }^{* * *} \mathrm{p}<0.01,{ }^{* *} \mathrm{p}<0.05,{ }^{*} \mathrm{p}<0.1$. 
Table A.15: The performance of dictatorship mayors in years without local elections

\begin{tabular}{|c|c|c|c|c|c|}
\hline & \multicolumn{3}{|c|}{ Panel data 1993-94 } & \multicolumn{2}{|c|}{ Cross-section } \\
\hline & $\begin{array}{l}\text { Budget } \\
\text { deficit }\end{array}$ & $\begin{array}{l}\text { Projects (number) } \\
\text { per capita }\end{array}$ & $\begin{array}{c}\text { Projects }(\$) \\
\text { per capita }\end{array}$ & $\begin{array}{l}\text { Change in } \\
\text { night lights } \\
(1992-94)\end{array}$ & $\begin{array}{c}\text { Change in } \\
\text { avg. wages } \\
(1992-94)\end{array}$ \\
\hline Panel A - Second stage & (1) & $(2)$ & (3) & (4) & $(5)$ \\
\hline Dictatorship mayor elected & $\begin{array}{c}0.05 \\
(0.04)\end{array}$ & $\begin{array}{l}-2.47 \\
(2.43)\end{array}$ & $\begin{array}{l}-375.37 \\
(337.63)\end{array}$ & $\begin{array}{l}-0.45 \\
(0.71)\end{array}$ & $\begin{array}{l}-1.14 \\
(0.76)\end{array}$ \\
\hline \multicolumn{6}{|l|}{ Panel B - First stage } \\
\hline Left-wing majority council & $\begin{array}{c}-0.23 * * * \\
(0.05)\end{array}$ & $\begin{array}{c}-0.23 * * * \\
(0.05)\end{array}$ & $\begin{array}{c}-0.23 * * * \\
(0.05)\end{array}$ & $\begin{array}{c}-0.23 * * * \\
(0.05)\end{array}$ & $\begin{array}{c}-0.19 * * * \\
(0.08)\end{array}$ \\
\hline Municipality-year observations & 205 & 205 & 205 & 103 & 46 \\
\hline Avg. dependent variable (panel A) & 1.00 & 2.19 & 432.6 & 0.734 & 0.364 \\
\hline $\mathrm{K}-\mathrm{P} F$-statistic & 20.1 & 20.1 & 20.1 & 19.8 & 5.8 \\
\hline
\end{tabular}

Notes: All specifications control by municipality size category and victory margin. Robust standard errors in parenthesis. Significance level: $* * * \mathrm{p}<0.01, * * \mathrm{p}<0.05, * \mathrm{p}<0.1$. 
Table A.16: Dictatorship mayors and category of projects 1993-1996

\begin{tabular}{|c|c|c|c|c|c|c|}
\hline \multirow[b]{3}{*}{ Panel A - Projects (N) per 10,000 inhab. } & \multicolumn{6}{|c|}{ Dependent variable is log of projects per capita } \\
\hline & All & Housing & Urban & Emergency & Conservation & Other \\
\hline & (1) & (2) & (3) & (4) & $(5)$ & (6) \\
\hline Dictatorship mayor elected & $\begin{array}{l}-1.0 \\
(2.9)\end{array}$ & $\begin{array}{c}-0.4 \\
(0.4)\end{array}$ & $\begin{array}{c}-0.3 \\
(0.7)\end{array}$ & $\begin{array}{c}-0.5 \\
(1.4)\end{array}$ & $\begin{array}{l}-0.4 \\
(0.4)\end{array}$ & $\begin{array}{c}0.5 \\
(1.1)\end{array}$ \\
\hline Avg. dependent variable & 2.5 & 0.2 & 0.8 & 0.6 & 0.3 & 0.6 \\
\hline \multicolumn{7}{|l|}{ Panel B - Projects (US\$) per 10,000 inhab. } \\
\hline Dictatorship mayor elected & $\begin{array}{l}-523 \\
(369)\end{array}$ & $\begin{array}{l}-322 \\
(211)\end{array}$ & $\begin{array}{l}-141 \\
(156)\end{array}$ & $\begin{array}{l}-10 \\
(14)\end{array}$ & $\begin{array}{l}-28 \\
(23)\end{array}$ & $\begin{array}{l}-23 \\
(42)\end{array}$ \\
\hline Observations & 411 & 411 & 411 & 411 & 411 & 411 \\
\hline Avg. dependent variable & 282 & 149 & 97 & 7 & 12 & 18 \\
\hline KP F-test & 20.18 & 20.18 & 20.18 & 20.18 & 20.18 & 20.18 \\
\hline
\end{tabular}

Notes: All specifications control by municipality size category and victory margin. Robust standard errors in parenthesis. Significance level: *** $\mathrm{p}<0.01, * * \mathrm{p}<0.05, * \mathrm{p}<0.1$. 